Historic, Archive Document

Do not assume content reflects current scientific knowledge, policies, or practices. 


\section{ENTERPRISE NURSERIES}

GEO. E. STEIN \& SON Wrightsville, R. D. No. 1

YORK COUNTY, PENNA.

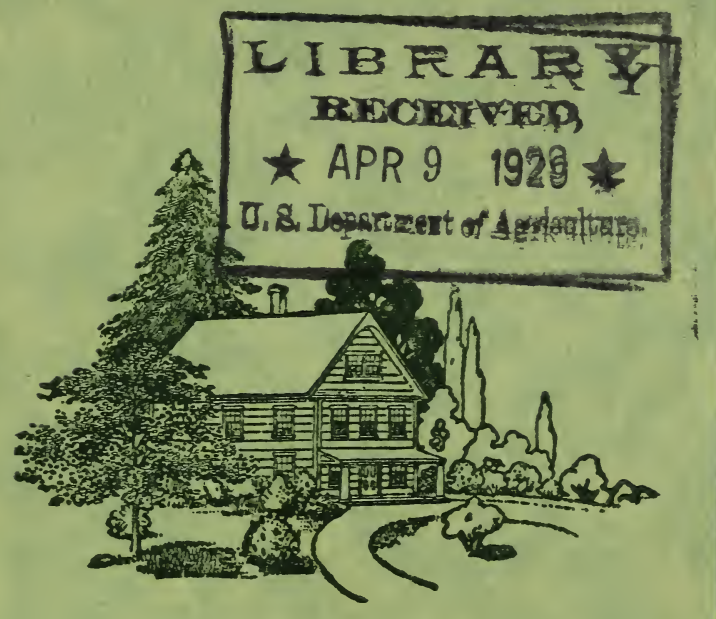

CATALOG

Growers of Quality Fruit and Ornamental Trees Evergreens, Shrubbery, Etc. 


\section{A Personal Message}

IN presenting our new catalog, we wish to emphasize the fact that it is hardly possible for us to express in words our appreciation to our many customers, for the business we have enjoyed during the past years in which we have been engaged in the nursery business.

We have tried to construct our new catalog in a plain straightforward way, so that all can understand it. We have tried to list the varieties that will prove best in this section of the country, giving a brief description of each. In many cases we have added to our list, especially in our ornamentals.

Your attention is called to the reduced prices in this catalog which you will find are in reach of all people. We have a good supply of healthy, vigorous and well-rooted trees and plants. And we are soliciting your valued orders, confident that you will be pleased with our stock, and join our many satisfied customers.

We thank you in advance for any business that you may place with us, and assure you it will at all times receive our best possible attention.

GEO. E. STEIN \& SON.

\section{Visit, Telephone or Write Us}

Location: East Prospect, $\mathbf{P a}$.

Telephone: Wrightsville Exchange

Post Office: Wrightsville, Pa.

Shipping Point: Hellam, Pa.

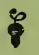

Table of Contents

Pages

Instructions to Purchasers.............. \&

Fruit Trees................... 3 to 8

Nut Trees................... 8

Small Fruits................. 8 to 10

Shade and Ornamental Trees.......... 11 to 13

Ornamental Shrubs............... 14 to 18

Hedge Plants ...................... 19

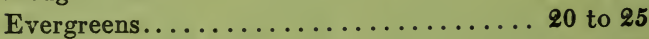

Broad-Leaved Evergreens........... 26 to 27

Ornamental Climbing Vines ......... 27 to 28

Hardy Perennial Plants................. 28

Roses....................... 28 to 29

Planting, Pruning and Care of Stock.... 29 to 30 


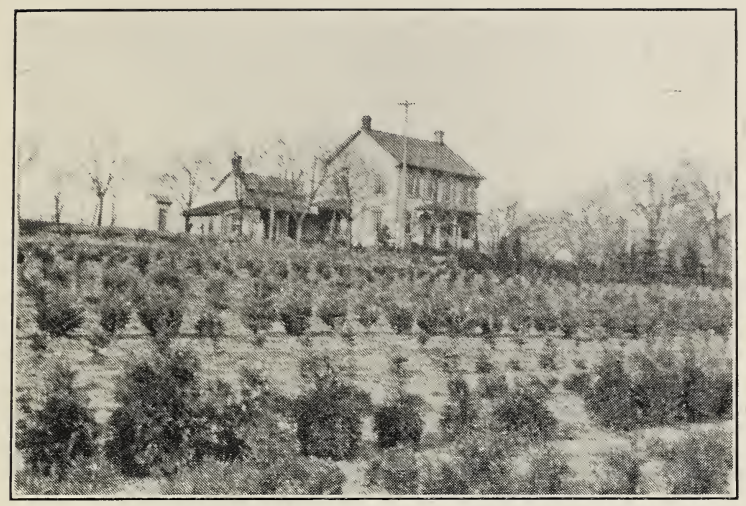

Thrifty, Young Evergreens at the Nursery

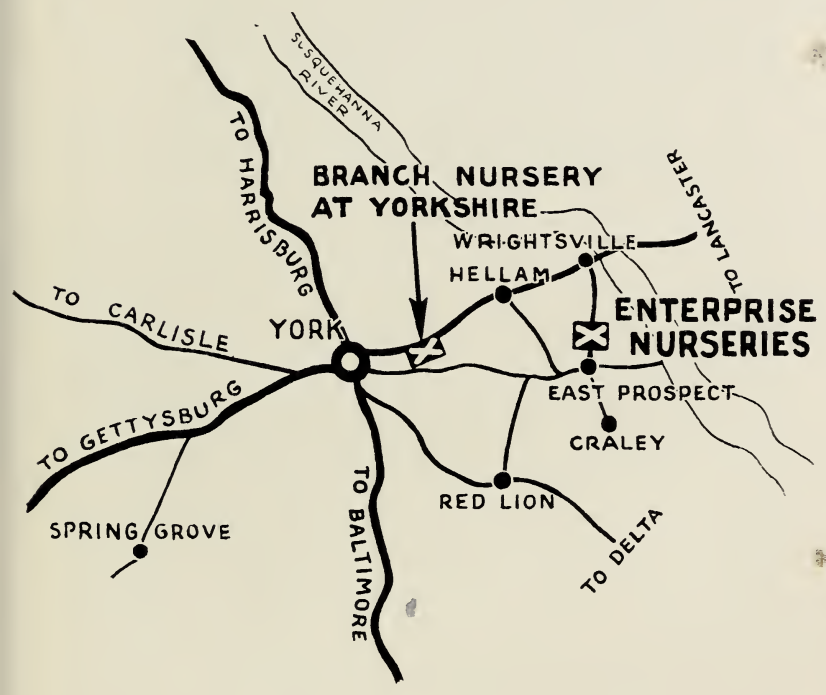

\section{HOW TO REACH THE NURSERIES}

Our Nursery and office are located one-half mile west of East Prospect on the road leading from East Prospect to Wrightsville.

Our Branch Nursery is located along the Lincoln Highway between York and Hellam, at Yorkshire.

If you are not acquainted with the location of our Nurseries, a little study of the above map will help you to get to us with very little, if any, trouble.

Visitors Welcome. But no business will be transacted on Sunday. 


\section{INSTRUCTIONS TO PURGHASERS}

Orders. Orders should be sent in just as soon as possible after receiving catalog. By placing orders early you are more certain of getting the varieties wanted, as late in the season we are usually sold out of some of the varieties. If ordered early we can reserve the stock until you want it shipped.

Shipping. We have the Pennsylvania Railroad and the York Trolley system, and can ship in any direction with the probability of prompt arrival at destination. All shipments travel at the cost and risk of the purchaser.

Truck Deliveries. Truck load orders will be delivered free, reasonable distances; long hauls and smaller orders delivered by special arrangement. We are well equipped to give good truck service.

Guarantee. We guarantee all stock to be strictly first class and true to name and will upon proper proof refund the purchase price, or replace any stock which proves otherwise. It is understood and agreed that we will not be held responsible for any greater sum than the cost of the stock, should any prove untrue. We strive to avoid mistakes and believe that we are as exact as any in the business.

Our nurseries are inspected every year and every shipment will be accompanied by a Certificate of the State Examiner.

Replacements. We guarantee all stock we sell to be strictly first-class and TRUE TO NAME, dug and packed properly for shipment; we do not charge a price for a tree that, should it die, we could replace it and then still make a profit. Stock often perishes when it is not properly planted and cultivated; also the severe cold and heavy storms of Winter and droughts of Spring and Summer, which are liable to occur, will sometimes cause the best of stock to perish, which is no fault of ours.

It is impossible for us to guarantee trees and plants to live, as this altogether depends on weather conditions and how stock is planted and cared for after planting. The conditions which prevail after stock leaves our hands are such that it is just as impractical for a Nurseryman to guarantee a tree or plant to live as it would be for your best neighbor to sell you a horse or other live stock and guarantee it to live. We can only guarantee to send you good stock up to grade represented, full of life and true to name. Upon request we will furnish 16-page planting booklet with every order.

Terms Cash, except when expressly agreed otherwise.

Substitution. When sold out of a variety of trees or plants we frankly say so, and when you allow us to substitute we will send a variety similar to the one ordered, as good or better; as we know the many varieties, our substitution, if any, will be of advantage. Late in the season we are sometimes sold out of some varieties of stock; thus when sending your order it is to your advantage to say whether we may substitute or not, that we may get the order off promptly, before the season is too far advanced for successful planting. If you do not wish us to exercise this right, please mark your order sheet plainly NO SUBSTITUTION.

\section{MEMBERS}

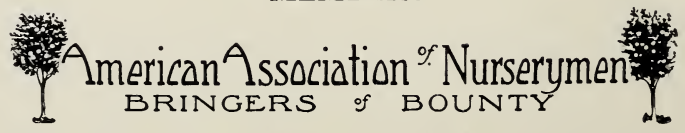

Pennsylvania Nurserymen's Association 


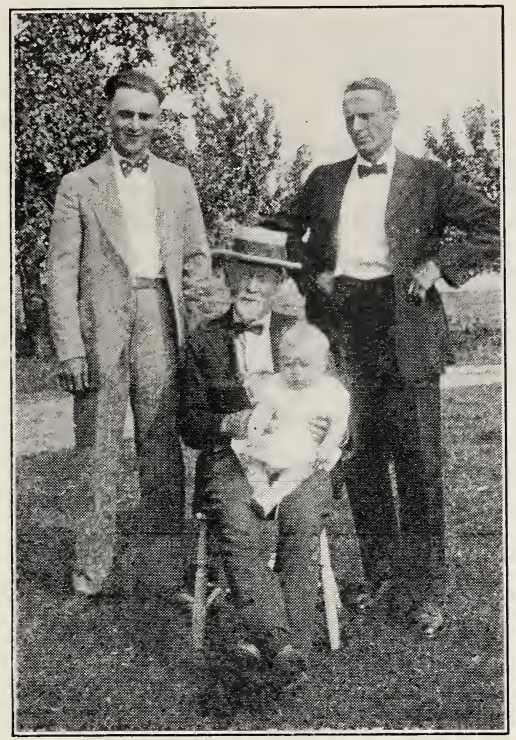

We Have Four Generations Here at the Nursery to Greet You

\section{APPLES}

Growing good Apple Trees is one of our specialties. Our list of varieties is confined to the best ones only. Most varieties of Apples on our list do well in all sections of the country where Apples are grown. For spraying instructions consult your County Agent or Experiment Station in your state.

$\begin{array}{rrr}\text { Each } & \text { Per 10 } & \text { Per } 100 \\ \$ .35 & \$ 3.00 & \$ 25.00 \\ .40 & 3.50 & 30.00 \\ .50 & 4.50 & 35.00 \\ .65 & 6.00 & \end{array}$

\section{SUMMER VARIETIES}

YELLOW TRANSPARENT. Earliest and best; white, tender, juicy, sprightly sub-acid; grows upright; bears when young, making good filler. July 1 to 15 .

EARLY HARVEST. Medium; pale yellow; tender, juicy. July 1 to 15.

EARLY RIPE. Of fair size; pale yellow; ripens little later than Early Harvest.

SUMMER RAMBO. Very large; greenish red, striped; tender, juicy; tree strong grower. August 15 to September 15 .

RED ASTRACHAN. Large, nearly covered with deep crimson, juicy, rich, acid, beautiful. Tree a vigorous grower. A good bearer. August.

EARLY STRAWBERRY. Tender, juicy, productive.

WATERMELON. Large, pale yellow; sweet, tender and juicy. Tree a compact grower and abudant bearer. August.

\section{FALL VARIETIES}

FALL PIPPIN. Large, yellow, rich, aromatic.

GRAVENSTEIN. Large striped, fine quality, one of the best fall sorts. 


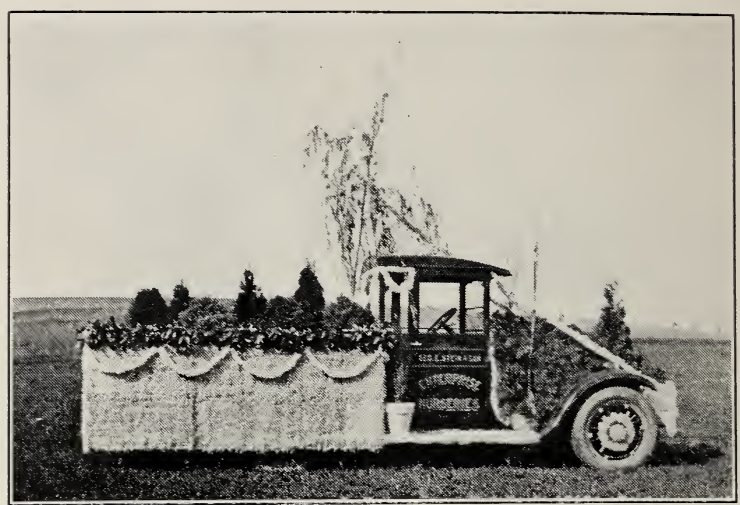

Our Nursery Float as Seen in the Sesqui Parade at York October, 1927

MAIDEN BLUSH. One of the most beautiful; pale lemon with crimson cheek; flesh white, tender and crisp. October.

WEALTHY. Fall. Almost solid red. Flesh white, tender, crisp, juicy, fine grained. A good keeper.

McINTOSH. Medium size, nearly covered with a bright red, flesh yellowish, tender, juicy, sub-acid.

SMOKEHOUSE. Fruit medium to large, uniform size and shape. Color yellow or greenish mottled with rather dark red, sometimes deepening to a solid bright red. October.

\section{WINTER VARIETIES}

GRIMES GOLDEN. Very large, skin golden yellow; flesh tender and crisp. A very good fall apple. September to January. Grown in all sections of the country.

STA YMEN'S WINESAP. November to April, but keeps well in May. A profitable sort to grow for market, and the best for home use. Large in size, fine appearance, good flavor, juicy and crisp, color red. A great success.

ROME BEAUTY. Large; roundish, slightly conical, with bright red on a pale yellow ground; fine grained, juicy, good quality.

DELICIOUS. Winter apple. Keeps well, color red and yellow, fine grained; and quite juicy, flavor slightly acid, but very good. A good apple for either home use or market.

YORK IMPERIAL. A very good one, trees come into bearing early, and bears a good crop each year. Skin bright yellow covered with bright red and striped, very large. Suitable to any part of the country.

JONATHAN. Most beautiful of all apples. Season November to April. Fruit medium to large, roundish, yellow nearly covered with red, fine grained, tender and finely flavored.

PARAGON. Winter. A round apple, of extra-large size; skin smooth, yellowish, covered with deep red, the general effect being dark red; flesh tender, tinged with yellow, crisp, sub-acid aromatic, of excellent quality in every way. Tree is vigorous and healthy and yields big crops every year.

WINTER BANANA. Size large, golden yellow and beautifully shaped with bright crimson red. Flesh lemon yellow, fine grained, sub-acid, rich, aromatic flavor. Season November to January. 
PARADISE WINTER SWEET. Large; creamy white, rosy cheeked. One of the best sweet winter varieties.

RHODE ISLAND GREENING. Large, greenish yellow, tender, juicy, rich, acid. The old reliable Winter cooking apple, and also good for dessert.

FALLAWATER (sometimes called Pound Apple). Large; yellowish green.

MANN. A round, attractive, greenish yellow apple; flesh fine grained, juicy, firm, good quality. October to April.

HUBBARDSTON. Large, red, striped, tender, juicy.

STARK. Large, striped, mild, sub-acid, good. Valuable as a keeper. January to May.

BALDWIN. Large, bright red, crisp, juicy, rich.

RAMBO. Medium, red and yellow. Mild flavor. Excellent old variety. October to December.

SENATOR. Tree vigorous, upright; fruit uniform in size and shape, fine grained, crisp, tender, very good. Color bright red, striped with carmine. November to March.

CORTLAND. A derivation from McIntosh, adding distinct perfections to that already very perfect apple. The tree: hardy, thrifty, early producing and long lived. The fruits: abundant, large, round.

\section{CRAB APPLES}

HYSLOP. Large; deep crimson; one of the most beautiful; very popular.

TRANSCENDENT. For many years the most popular crab apple. Fruit about an inch in diameter, yellow, with red cheek.

\section{PEACHES}

We are offering only a limited number of varieties, ones that you can depend on giving you a good crop of fruit. We do not think it worth while to propagate a large number of varieties, when a few of the best will make more money for our customers. The peach crop is quite sure if you give your trees proper attention.

Each Per 10 Per 100

$\begin{array}{llrrr}\text { Light first-class, } 3 \text { to } 4 \mathrm{ft} \ldots \ldots \ldots \ldots & \$ .25 & \$ 2.00 & \$ 15.00 \\ \text { First-class, } 4 \text { to } 5 \text { ft.............. } & .30 & \mathbf{2 . 5 0} & \mathbf{2 0 . 0 0}\end{array}$

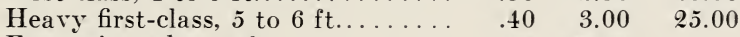

Extra size, $5 \frac{1}{2}$ to $7 \mathrm{ft} . \ldots \ldots \ldots \ldots . . .50$

\section{VARIETIES ARRANGED IN ORDER OF RIPENING}

SNEED. Bright red cheeks. Earliest market Peach. July 1.

CARMAN. Large, creamy white skin, mostly covered red; tender, juicy. Good commercial shipper. July 15 to August 1.

HILEY (early Belle). The earliest commercial white freestone Peach. It resembles Belle of Georgia, but in quality is superior to most of its white-fleshed competitors. The pretty red cheek and good shipping qualities make it very popular for early market. Mid-July to August 1.

ROCHESTER. Has the habits and characteristics of the Crawford, but fully two weeks earlier. Yellow, freestone, good size, very sweet and fine flavor. Requires only half the usual a mount of sugar for canning. Ripens about the middle of July.

CHAMPION. A large, handsome, early variety. Creamy white with red cheek; sweet, rich and juicy; hardy and productive. August 1.

BELLE OF GEORGIA. Very large Peach with red cheek; flesh white and firm, of excellent flavor; fine shipper. August 1 to 15 . 
OLD MIXON. A showy, white fleshed peach with a bright red cheek. Very large, juicy, sweet and good. Is freestone and ripens near the end of September.

ELBERTA. Mid-season. A valuable large peach, of good quality; fruit large, yellow with red cheek; juicy and extremely high flavored; flesh yellow; freestone. The leading market variety. Ripens here about the middle of August.

J. H. HALE. One of the best sorts for market or garden. Fruit is very large, round, quality excellent. Skin yellow finely colored, flesh yellow, sweet and melting. Ripens just before the Elberta. A very good one.

CRAWFORD'S LATE. Large, yellow Peach, fine for canning and market. September 1 to 15 .

GOLD DROP. Medium size, hardy, very productive, good quality, early bearer. Last of September.

STEPHEN'S R. R. White, partly covered with red. A fine-flavored Peach of good size and a splendid market variety. September 1 to 15 .

SMOCK. One of the best of the late varieties, ripening about three weeks after Elberta. It is of large size, with yellow flesh. Very desirable market Peach.

SALWAY. A late yellow variety. Latter part of September to October 15.

IRON MOUNTAIN. Ripens September 15. Freestone. Fruit is of large size; color, white.

BILYEU. Large; nearly covered with dark red; flesh white, rich, juicy and firm. A good shipper; rather late. Middle to last of October.

\section{PLUMS}

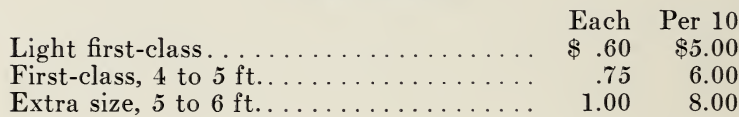

ABUNDANCE. One of the oldest and best varieties; hardy, productive. Fruit large, lemon yellow, with heavy bloom; good quality. August.

BURBANK. Most profitable a mong growers for market; ripens ten days after Abundance. Tree hardy.

OCTOBER PURPLE. A strong, vigorous grower, hardy, productive, of good quality; a large, round, late purple plum, especially recommended for late market.

RED JUNE. One of the vigorous, upright growers; productive; fair size, vermilion red; pleasant quality. Ripens a week before Abundance. August.

CLIMAX. One of the best of the large, early sweet plums, ripening ahead of other varieties, which makes it a very valuable market sort. July.

GOLD. Large, oval, bright yellow; rich, juicy, fine quality. A good grower.

BRADSHAW. A very large and fine early plum, dark violet red, juicy and good. Very productive; valuable for market. The tree is very hardy and vigorous. Middle of August.

GERMAN PRUNE. Large, dark purple, sweet, good. One of the most popular for canning, because of its sweetness. September.

ITALIAN PRUNE. Good size, purple, juicy, delicious, fine for drying. September.

\section{PEARS}

Light first-class.................. $\$ \$ .60 \quad \$ 5.00$

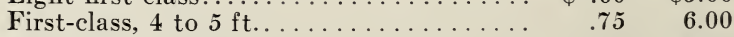

Extra size, 5 to $6 \mathrm{ft} \ldots \ldots \ldots \ldots \ldots \ldots \ldots$. $1.00 \quad 8.00$ 
BARTLETT. Season last of August to September 15 th. Good strong grower, flesh is white, fine grained, luscious, large and buttery, has a rich melting flavor and very sweet.

CLAPP'S FAVORITE. Summer. Fruit large, yellow lemon color, spotted with brown dots; flesh fine, rich and sweet. A very good one.

DUCHESS. Strong grower, productive, not subject to blight. Fruit large, light green patched with russet, melting, juicy, sweet and good. October and November.

KIEFFER. One of the most prolific pears. It is an abundant and regular bearer. Good shipper. Fruit large, color yellow with red cheek. Will produce ten bushels of pears to the tree when ten years old, begins fruiting successfully when three years old. Season October.

SHELDON. A large, round, russet and red pear of very fine quality; melting, rich, and delicious. Tree vigorous, erect, and handsome; bears well and should be more largely planted. October.

LAWRENCE. Medium, yellow with brown dots, melting, pleasant, aromatic. November and December.

SECKEL. Medium size, skin rich, yellowish brown with deep brownish red cheek when fully ripe; flesh very fine grained, sweet, exceedingly juicy, melting, buttery. One of the richest and highest flavored pears known. Summer.

\section{CHERRIES}

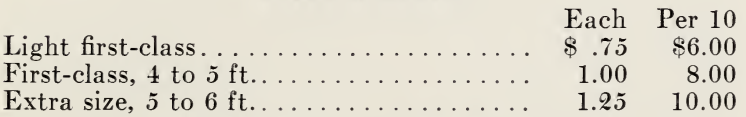

\section{SWEET CHERRIES}

NAPOLEON. Large, pale yellow or red; firm, juicy, sweet and productive.

SCHMIDT. Immense size, deep black, flesh dark, tender, very juicy, fine flavor; productive.

WINDSOR. Fruit large, liver-colored, distinct, flesh remarkably firm and of fine quality. Tree hardy and prolific. A valuable late variety.

YELLOW SPANISH. Large, yellow and red. June.

BLACK TARTARIAN. Very large, black, juicy. Last of June.

OX HEART. Large, light red, juicy, rich, delicious. Tree healthy and productive. June.

\section{SOUR CHERRIES}

BALDWIN. Large, round, slightly sub-acid, sweetest and richest of the Morello type. June.

EARLY RICHMOND. A dependable variety which seldom misses a crop. Medium, dark red, melting, juicy, sprightly, rich acid, best. June.

LARGE MONTMORENCY. Large, red, productive, ten days later than Early Richmond.

\section{APRICOTS}

$\begin{array}{llr}\text { Light first-class } \ldots \ldots \ldots \ldots \ldots \ldots \ldots \ldots \ldots & \begin{array}{r}\text { Each } \\ \$ .60\end{array} & \begin{array}{r}\text { Per } 10 \\ \$ 5.00 \\ \text { First-class, } 4 \text { to } 5 \mathrm{ft} \ldots \ldots \ldots \ldots \ldots \ldots \ldots \ldots\end{array} \\ \text { Extra size, } 5 \text { to } 6 \mathrm{ft} \ldots \ldots \ldots \ldots \ldots \ldots \ldots \ldots & .75 & 6.00 \\ \end{array}$

EARLY GOLDEN. Small, pale orange, juicy and sweet.

DALLAS. Fruit large, round, early, deep yellow with a fine blush; flesh yellow, firm, juicy and excellent. Tree hardy, a good grower.

ROYAL. Large, yellow, juicy, rich and delicious; a very fine variety. 


\section{QUINCES}

Each Per 10

Light first-class . . . . . . . . . . . . . $\quad \$ .60 \$ 5.00$

First-class, 4 to $5 \mathrm{ft} . \ldots \ldots \ldots \ldots \ldots \ldots \ldots$. $.75 \quad 6.00$

Extra size, 5 to $6 \mathrm{ft} \ldots \ldots \ldots \ldots \ldots \ldots . \quad 1.00 \quad 8.00$

ORANGE. Fruit large, bright yellow, of excellent quality. CHAMPION. A prolific and constant bearer of oval fruit, averaging larger than Orange and ripening later. A long keeper.

MEECH PROLIFIC. A vigorous grower and immensely productive of large, orange-yellow fruit of delightful flavor, and fine cooking quality.

\section{NUT TREES}

Nut trees are valuable, useful and ornamental. No home should be without them. They are valuable as shade and ornamental trees, as well as for the nuts they produce. ENGLISH WALNUT. Well known, justly popular, very hardy, will stand the extreme cold, produces abundantly.

2 to $3 \mathrm{ft} . \ldots 1.00$

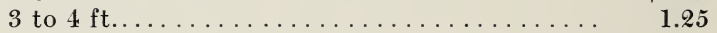

ALMOND. Very hardy, makes quick growth, bears abundantly when young.

Each

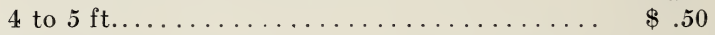

JAPAN CHESTNUT. This is a new blight resistant variety, very hardy, makes quick growth, bears abundantly when young, produces large nuts of excellent quality.

seedlings . . . . . . . . . . . . \$1.00

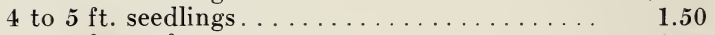

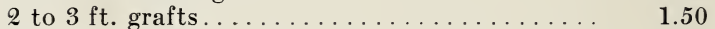

3 to $4 \mathrm{ft}$. grafts $\ldots \ldots \ldots \ldots \ldots \ldots \ldots \ldots \ldots \ldots . \ldots \ldots$

\section{MULBERRIES}

DOWNING. Very large, black, handsome, sweet, rich, and excellent.

Each

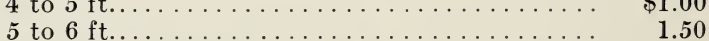

RUSSIAN. Tree is a spendid grower, soon attains good size, fruit very heavy regularly, a good crop of the most delicious mulberries. Trees bear when quite young, beginning second year in the nursery row.

5 to $6 \mathrm{ft}$........

\section{SMALL FRUITS GRAPE-VINES \\ Each Per 10 Per 100}

2 years old . . . . . . . . . . . . . . $\$ \$ \$ .30 \quad \$ 2.50 \quad \$ 20.00$

Grape-Vines should be planted six to eight feet apart, in rows eight feet apart.

BRIGHTON. Large, handsome berries of high quality. One of the most popular reds.

CONCORD. The leading market, vineyard and homegarden variety. Dark blue berries of fine quality. 


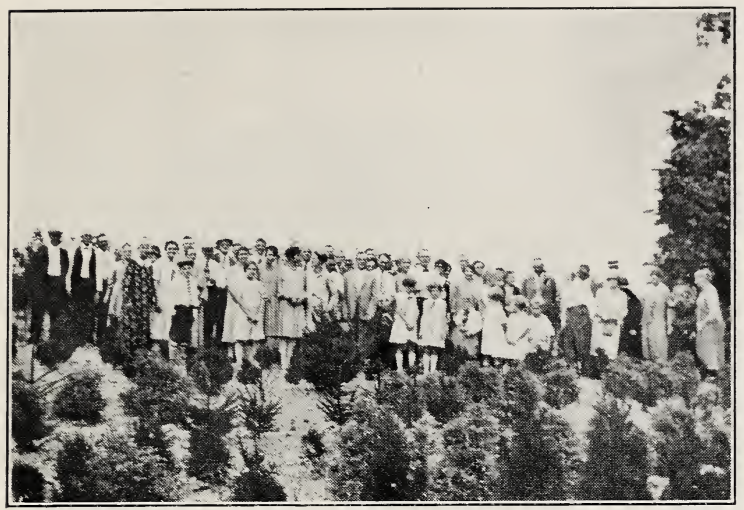

A Group of Visiting Grange Friends at the Nursery

WORDEN. Resembles Concord but is sweeter, larger in bunch and berry, and a week to ten days earlier than that variety.

NIAGARA. The standard white Grape. It ripens with Concord but the bunches and berries are larger; very sweet.

MOORE'S EARLY. Bunch medium; berry large, round; vine exceedingly hardy. Ripens three weeks ahead of the Concord, making it desirable for early market.

POCKLINGTON. Beautiful golden color when fully ripe, enchanting the delight of its luscious sweetness and individual flavor. Ripens late and keeps well.

AGAWAM. Deep red or maroon. Fruit large and meaty, borne in extra large, loose-shouldered bunches. Vine strong grower, very healthy. Ripens with Concord. Has a delightful aromatic flavor.

CATAWBA. One of the longest keeping grapes in cultivation. Ripens late and can be kept in good condition a long time. Flavor sprightly and attractive. The bunch and berry is medium in size and red in color.

MOORE'S DIAMOND. Ripens early, just before Moore's Early. Prolific grower. Berries large greenish white, juicy and of good quality. Bunches are compact. A standard white grape.

\section{GURRANTS}

$\begin{array}{ccc}\text { Two years old, strong plants.......... } & \text { Each } & \text { Per } 10 \\ \$ .30 & \$ 2.50\end{array}$

FAY'S PROLIFIC. A very vigorous growing bush, enormously productive, with fruit of very large size. Inclined to do better on light soils than most varieties. Popular with most growers.

CHERRY. Large berries on short clusters; a robust fruitful sort. The vigorous, stocky bushes produce great quantities of bright red fruit. The berries have thin skins, and possess a remarkable fine flavor.

WHITE GRAPE. Very large; yellowish white; sweet or very mild acid; valuable for the table.

\section{GOOSEBERRIES}

Each Per 10

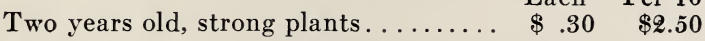

DOWNING. Large, handsome, pale green, and of splendid quality for both cooking and table use; bush vigorous grower, and usually free from mildew. 
HOUGHTON. Medium; roundish, oval, pale red, sweet, tender, very good; plants spreading; shoots slender, enormously productive.

\section{BLACKBERRIES}

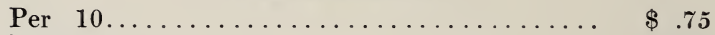

Per $100 \ldots \ldots \ldots \ldots \ldots \ldots \ldots \ldots \ldots \ldots \ldots$

BLOWERS. Claimed to be the hardiest and most productive. Large size, Jet black; good shipper. Unexcelled productiveness are the main characteristics of this splendid new sort.

ELDORADO. Jet Black. Berries are large to very large, of finest quality. Plants are vigorous and seldom fail to produce a bumper crop.

\section{RASPBERRIES}

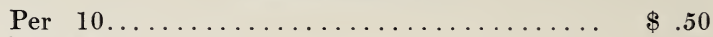

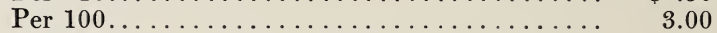

CUMBERLAND. Produces large jet black fruit, firm and of excellent quality; sweet and mild, ripening in midseason and continuing for two weeks. Extensively planted for commercial purposes and for table use.

CUTHBER'T (Red). The best red raspberry. Heavy yielder of large solid fruit. Plant is a very vigorous grower. Fine for market and table use.

\section{STRAWBERRIES}

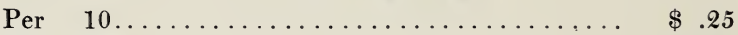

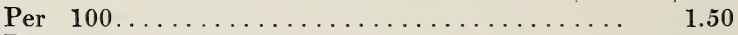

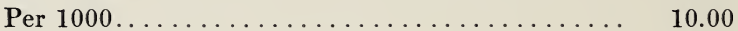

PREMIER. Extra early. Fruit large, deep red clear through to the center. Specially recommended for home use and in markets.

BIG JOE. Late. Ripens with Chesapeake, about three days before Gandy. Fruit is firm, of large size, and has a good flavor. If you are not growing Joe plant heavily of them this spring.

WILLIAM BELT. A handsome variety that is giving remarkable satisfaction as a large productive berry for market or home use.

CHESAPEAKE. Late. Fruit uniformly large, firm, and without green tips; does best in rich damp land.

\section{ASPARAGUS-Strong, Healthy Roots}

2 Year

Per $100 \ldots \ldots \ldots \ldots \$ 1.75$

Per $1000 \ldots \ldots \ldots \ldots 12.00$
1 Year

Per $100 \ldots \ldots$.

Per $1000 \ldots \ldots$.

PALMETTO. A very early variety; even regular size, of excellent quality.

WASHINGTON. A new rust-resistant pedigreed Asparagus. As a standard variety for the production of fancy Asparagus for the home or market, it stands ahead of all others in size, vigor, tenderness, quality, and rustresistance.

\section{RHUBARB OR PIE PLANT}




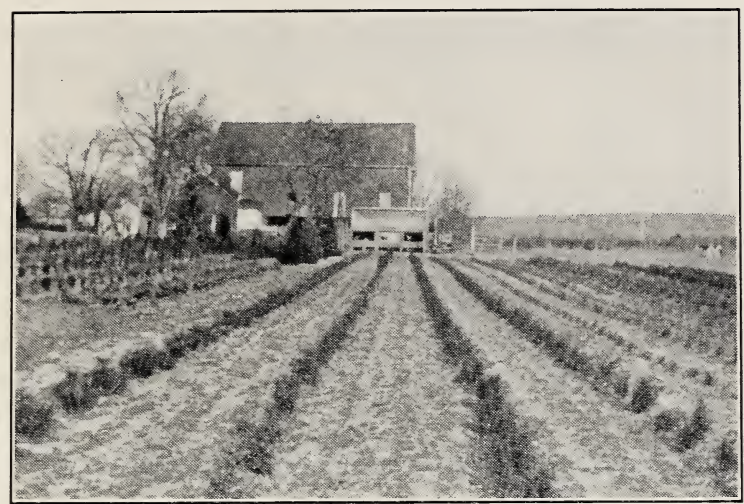

One of Our Young Evergreen Blocks

\section{SHADE AND ORNAMENTAL TREES MAPLES}

NORWAY MAPLE

(Acer platanoides)

Most popular and best known shade tree. Green foliage remains until late fall and turns to rich yellow.

\begin{tabular}{|c|c|}
\hline & Each \\
\hline 5 to $6 \mathrm{ft}$. & $\$ 1.50$ \\
\hline 6 to $8 \mathrm{ft}$. & 2.00 \\
\hline 8 to $10 \mathrm{ft}$ & 3.00 \\
\hline 0 to $12 \mathrm{ft}$ & 4.00 \\
\hline
\end{tabular}

SILVER MAPLE (Acer dasycarpum)

Tall, stately tree, rapid grower, graceful, leaves silvery underneath.
6 to $8 \mathrm{ft}$.
$\$ 1.25 \$ 10.00$
8 to $10 \mathrm{ft} . \ldots \ldots \ldots \ldots \ldots \ldots \ldots \ldots \ldots \ldots$
$1.75 \quad 15.00$

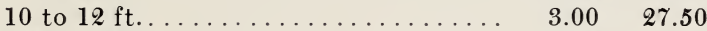
12 to $14 \mathrm{ft} . \ldots \ldots \ldots \ldots \ldots \ldots \ldots \ldots$

WIER'S CUT-LEAVED MAPLE

(Acer saccharinum wieri) Graceful, drooping form; very desirable.
6 to $8 \mathrm{ft}$
$\$ 1.75 \$ 15.00$
8 to $10 \mathrm{ft}$.
$2.50 \quad 22.50$
10 to $12 \mathrm{ft}$.
4.00

\section{SCHWEDLER'S RED-LEAVED MAPLE}

(Acer platanoides schwedleri)

Probably the best large growing purple leaf tree. Useful as lawn specimen.

6 to $8 \mathrm{ft} . \ldots \ldots \ldots \ldots \ldots \ldots \ldots \ldots \ldots \ldots$

\section{JAPANESE BLOODLEAF MAPLE}

(Acer palmatum atropurpureum) A good dwarf tree with rich purple-red leaves all summer. Best in sun.

12 to $15 \mathrm{in}$. selected seedlings . . . . . $\$ 2.00$

12 to 15 in. grafts. . . . . . . . . . . 3.50

\section{BIRCH}

\section{EUROPEAN WHITE BIRCH}

Known by its white bark.

(Betula alba)
4 to $5 \mathrm{ft}$
$\$ 1.75$
5 to $6 \mathrm{ft}$.
2.00

6 to

$8 \mathrm{ft}$.

2.50 
GUTLEAF WEEPING BIRCH

Graceful tree for lawn planting. Very graceful.

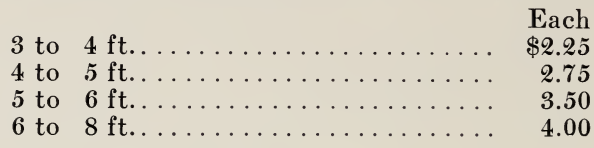

Per 10

\section{CATALPA}

UMBRELLA CATALPA

Useful in formal planting.

(Catalpa Bungei)

Light Heads 5 to $6 \mathrm{ft}$.

$\$ 1.75 \$ 15.00$

Medium Heads 5 to $6 \mathrm{ft} . \ldots \ldots \ldots \ldots \ldots . \quad 2.50 \quad 22.50$

Large Heads 5 to $6 \mathrm{ft} \ldots \ldots \ldots \ldots \ldots \ldots$. $3.50 \quad 32.50$

WESTERN CATALPA

6 to $8 \mathrm{ft}$

(Catalpa Speciosa)

$\$ 1.25 \$ 10.00$

\section{DOGWOOD}

WHITE FLOWERING DOGWOOD (Cornus florida) Among the best of the spring flowering small trees.

3 to $4 \mathrm{ft} \ldots \ldots \ldots \ldots \ldots \ldots \ldots \ldots \ldots \ldots$

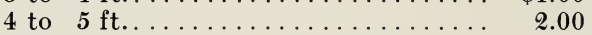

RED FLOWERING DOGWOOD (C. florida rubra)

The pink flowers are more persistent than the white.

18 to 24 in.................. $\$ 3.00$

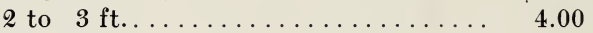

\section{PLANE TREES}

ORIENTAL PLANE

(Platanus orientalis)

A good tree for park and street use; grows rather quickly; withstands smoky city conditions.

6 to $8 \mathrm{ft} . \ldots \ldots \ldots \ldots \ldots \ldots \ldots \ldots \ldots$

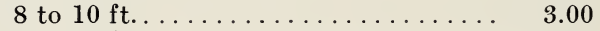

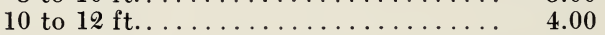

AMERICAN PLANE (Platanus Occidentalis)

Common Sycamore. Fast growing, tall tree.

6 to $8 \mathrm{ft} . \ldots \ldots \ldots \ldots \ldots \ldots \ldots \ldots . \ldots 1.75 \quad \$ 15.00$

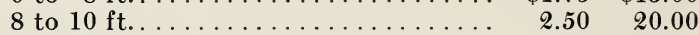

10 to $12 \mathrm{ft} . \ldots \ldots \ldots \ldots \ldots \ldots \ldots \ldots . \quad 3.50$

\section{WILLOWS}

Rapid growing trees desirable for quick effects. Of distinctive form, making pleasing contrast with other trees. Must not necessarily be planted near water.

BABYLON WEEPING WILLOW (Salix Babylonica) Pretty as single specimen to contrast with upright trees and particularly attractive near water; branches olivegreen, slender and drooping.
5 to $6 \mathrm{ft}$.
$\$ 1.00 \quad \$ 7.50$

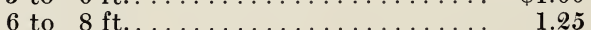
10.00
8 to $10 \mathrm{ft}$.
1.75

\section{WEEPING GOLDEN WILLOW}

Weeping habit, (Salix Babylonica pendula) to Babylonica, with yellow branches.
5 to $6 \mathrm{ft}$

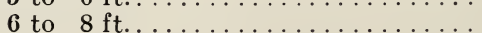


PUSSY WILLOW

(Salix discolor)

Shrub-like tree with furry catkins in early spring.

3 to $4 \mathrm{ft} \ldots \ldots \ldots \ldots \ldots \ldots \ldots \ldots . .5 \ldots \ldots$

4 to $5 \mathrm{ft} . \ldots \ldots \ldots \ldots \ldots \ldots \ldots \ldots$

\section{POPLAR TREES}

LOMBARDY POPLAR (Populus nigra Italica) Tall spire-like character; valued for landscape work and screens.
6 to $8 \mathrm{ft}$
$\$ .75 \$ 6.00$
8 to $10 \mathrm{ft}$.
$1.00 \quad 9.00$
10 to $12 \mathrm{ft}$
1.50
13.50

\section{CAROLINA POPLAR}

(Populus eugenei)

$A$ rapid grower; succeeds even in dry places and near seashore.

8 to $10 \mathrm{ft} . \ldots \ldots \ldots \ldots \ldots \ldots \ldots \ldots \ldots$

10 to $12 \mathrm{ft} . \ldots \ldots \ldots \ldots \ldots \ldots \ldots . \ldots \ldots$

\section{OTHER WELL-KNOWN VARIETIES OF ORNAMENTAL TREES}

\section{PURPLELEAF PLUM}

(Prunus pissardi)

Valued chiefly because of purplish foliage; should be pruned every year for best color effect.

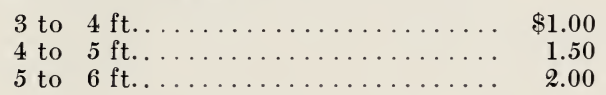

TULIP TREE (Liriodendron tulipifera) A quick grower; the yellow tulip-like flowers are produced in June.
6 to $8 \mathrm{ft}$
$\$ 1.50$
8 to $10 \mathrm{ft}$.
2.00

\section{SAUCER MAGNOLIA}

(M. soulangeana) Large purplish-pink and white flowers in May. Best transplanted in early spring.

$$
5^{\prime \prime} \text { pots............... \$3.00 }
$$

BECHTEL FLOWERING CRAB (M. ioensis plena) Large double pure pink flowers with noticeable fragrance; vigorous grower.
2 to $3 \mathrm{ft} . \ldots \ldots \ldots \ldots \ldots \ldots \ldots \ldots \ldots$
4 to $5 \mathrm{ft} . \ldots \ldots \ldots \ldots \ldots \ldots \ldots \ldots \ldots$

TEA'S WEEPING MULBERRY (M. alba pendula) The most popular small "weeping" tree.

Medium grade.................. \$2.25

Large heads................... $\quad 3.00$

\section{AMERICAN ELM (Clmus Americana)} Stateliness and dignity are here exemplified. Fairly rapid in growth, this typical American tree soon assumes regal proportions and commands respect of all who look upon it.

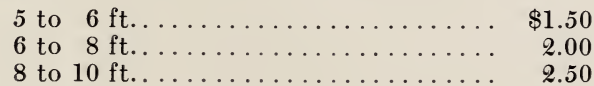




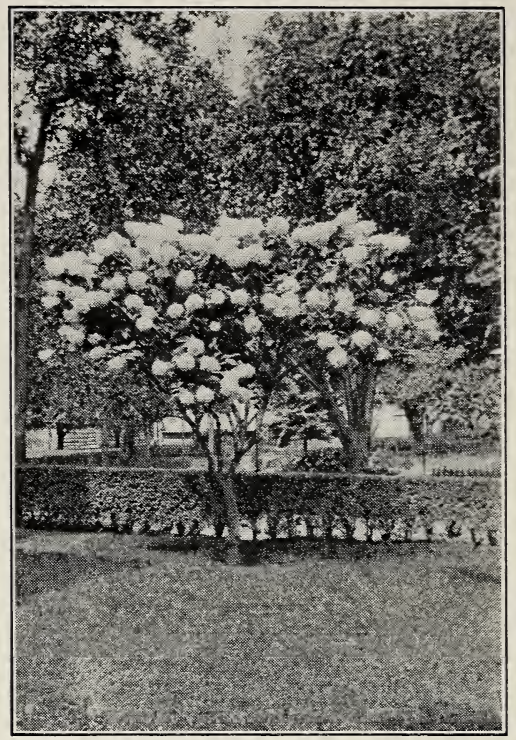

Hydrangea P. G. and California Privet Hedgeon Our Lawn

\section{ORNAMENTAL SHRUBS}

Five or more of one kind-10c less per plant, except Barberry-5c less.

\section{HYDRANGEAS}

Among the best and most popular shrubs, valuable for their wealth of late summer blooms.

PEEGEE HYDRANGEA

(Paniculata Grandiflora)

Large flowers, first snowy white, then pink, then reddish bronze and green. Blooms from middle summer until fall. Best selling variety of Hydrangeas grown.

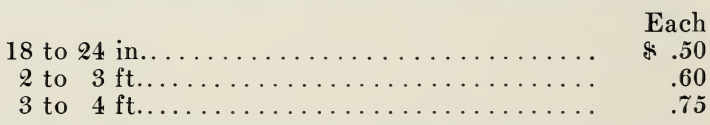

TREE HYDRANGEA (Paniculata grandiflora) (standard) Flowers similar to bush form.

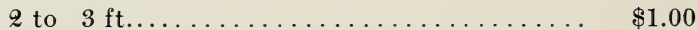

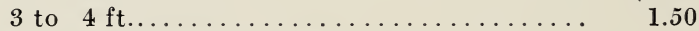

\section{HILLS OF SNOW HYDRANGEA}

(Aborescens grandiflora)

Conspicuous white and imposing white flowers in great clusters during mid-summer. Suitable for shady places.

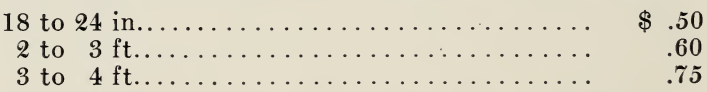

PINK AND BLUE HYDRANGEA (Hydrangea otaksa)

Old favorite Southern Hydrangea, not hardy in the North. Color depends upon the acidity of soil. Very attractive and popular.

12 to 18 in....................... $\$ .75$

18 to 24 in....................... 1.00 


\section{SPIREAS}

VAN HOUTTE SPIREA

(Spirea vanhouttei)

Grandest of all Spireas; very desirable shrub. Abundance of pure white blooms, graceful habit.

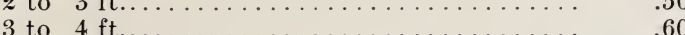

BILLARDI SPIREA

(Spirea billardi)

Bright pink fluffy flower spikes, July-October. Valuable for dry places.

18 to 24 in..................... \$ .50

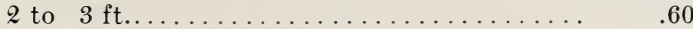

ANTHONY WATERER SPIREA

Deep rose pink; very free flowering all summer.

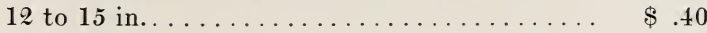

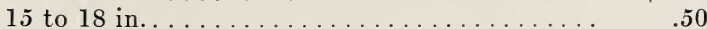

18 to 24 in..................... .60

JAPANESE SPIREA (Callosa alba)

White, June-July. Purplish-green foliage when young.

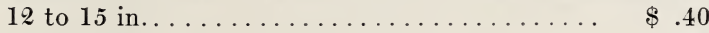

15 to 18 in.................... .50

BLUE SPIREA (Caryopteris incana)

Lavender-blue flowers, Sept.-Oct. Spendid for massing.

Requires protection.

12 to 18 in..................... \$ $\$ .40$

18 to 24 in....................... . . . .

THUNBERG'S SPIREA (Spirea thunbergi)

White flowers with feathery, yellowish green foliage.

18 to 24 in.

$\$ .50$

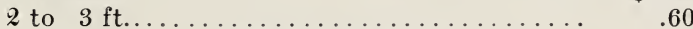

\section{DEUTZIAS}

Handsome flowered shrubs of low and medium height for the garden or border. The pretty flowers may be cut for house decoration in early summer.

DEUTZIA GRACILIS

Profuse bloomer, pure white, May. Useful "facing", shrub.

12 to 18 in..................... \$ .50

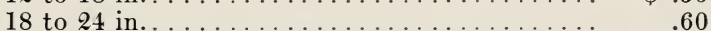

MAGNIFICENT DEUTZIA (Deutzia crenata magnifica)

A most distinct variety with exceptionally large clusters of pure white double flowers, produced in wonderful profusion. Easily the finest of all Deutzias.

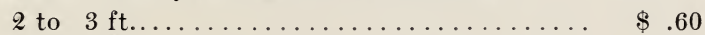

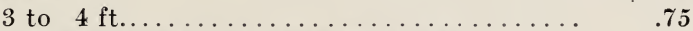

DEUTZIA PRIDE OF ROCHESTER

Vigorous, large flower tinged pink, June.

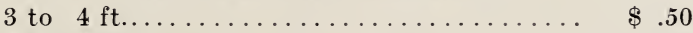

4 to $5 \mathrm{ft} \ldots \ldots \ldots \ldots \ldots \ldots \ldots \ldots \ldots \ldots \ldots \ldots \ldots$

\section{MOCK-ORANGES}

SWEET MOCK-ORANGE (Philadelphus coronarius)

White frangrant flowers profusely borne in May-June.

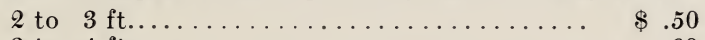

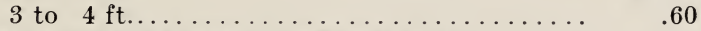

GOLDEN LEAF MOCK-ORANGE (P. coronarius a ureus) Brilliant yellow foliage in spring, holding color fairly well throughout the summer. White flowers, May and June.

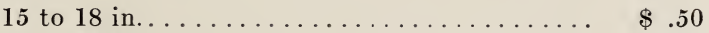

18 to 24 in..................... 60 


\section{VIRGINAL MOGK-ORANGE}

(P. virginalis)

Here is the most beautiful variety of its class. It produces large double-crested flowers of pure white, deliciously fragrant. Blooms two and one-half inches across and in May and early June completely cover the branches. Bloom all summer.

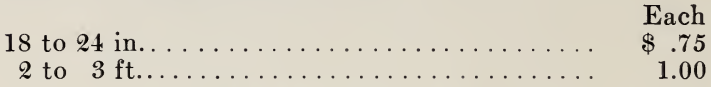

\section{BUSH HONEYSUCKLE}

MORROW HONEYSUCKLE (Lonicera morrowii)

White flowers in May and June, followed in July and August with bright red fruit.

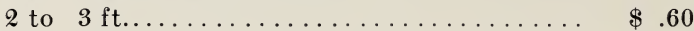

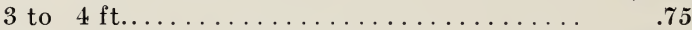

TATARIAN HONEYSUCKLE (L. tatarica)

Pink, red and white flowers and fruit freely produced. A most adaptable shrub. Please state color wanted.

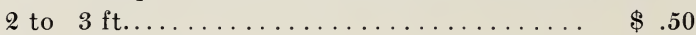

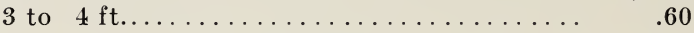

\section{GOMMON LILAC}

\section{LILACS}

Will never lose its popularity. Purple (Syringa vulgaris)

18 to 24 in.

$\$ .50$

WHITE LILAC

(S. vulgaris alba)

The familiar white flowering variety blooming in May.

18 to 24 in. $\$ .50$

PERSIAN LILAC

(S. persica)

Attractive, small-leaved variety with rather small, loose panicles of pale-lilac flowers, in May and June.

18 to 24 in................... \$ .60

\section{FRENGH LILAC}

(President Grevy)

Improved form of Lilac with larger, more fragrant and earlier clusters of flowers; double blue.

2 to
3 to $\quad 4 \mathrm{ft} . \ldots \ldots \ldots \ldots \ldots \ldots \ldots \ldots \ldots \ldots \ldots \ldots \ldots \ldots \ldots \ldots \ldots \ldots \ldots \ldots \ldots \ldots \ldots \ldots$

\section{SNOWBERRY}

Valued for planting in partially-shaded places and for the showy, attractive berries of autumn. Small, pink flowers in clusters all summer.

SNOWBERRY (Symphoricarpos racemosus) Waxy, showy snow-white berries in autumn, as large as cranberries. Effective in masses.

18 to 24 in. ...................... \$ $\$ .50$

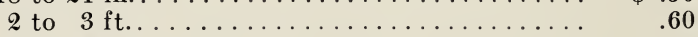

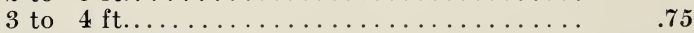

CORALBERRY (S. vulgaris)

In autumn and winter its long, slender branches, covered with racemes of coral-red berries, bend gracefully to the ground. Very attractive.

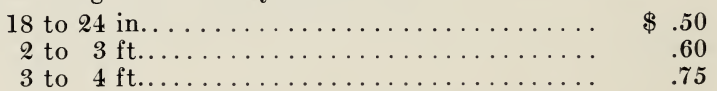

SNOWBALL-VIBURNUM

JAPANESE SNOWBALL (Viburnum plicatum) Upright, somewhat spreading habit; covered in June with dense heads of snowy-white flower-clusters, which have a beautiful setting in the deep green foliage.

18 to 24 in....................... \$ .75

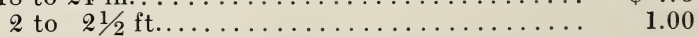




\section{EUROPEAN GRANBERRY-BUSH}

(V. opulus)

Flat heads of showy, white flowers, three to four inches across, May and June, followed by clusters of bright scarlet fruit, remaining over winter.

Each

18 to 24 in...................... \$.60

2 to $3 \mathrm{ft} \ldots \ldots \ldots \ldots \ldots \ldots \ldots \ldots \ldots \ldots \ldots \ldots \ldots \ldots \ldots \ldots . .75$

\section{WEIGELA}

Popular and showy shrubs whose branches bend beneath the weight of their abundance of pretty flowers, resembling in form the honeysuckle. Needed in all shrub borders, large or small.

RED-FLOWERED WEIGELA (Weigela Eva Rathke) The Everblooming Weigela. Dark red flowers, marked white, and splendid foliage produce an effect not to be had in any other shrub; flowers continuously.

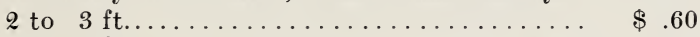

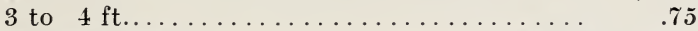

PINK WEIGELA

(Weigela rosea)

Showy, pink flowers freely produced. June. Vigorous grower.

2 to $3 \mathrm{ft} \ldots \ldots \ldots \ldots \ldots \ldots \ldots \ldots \ldots \ldots \ldots \ldots \ldots \ldots \ldots \ldots \ldots \ldots$

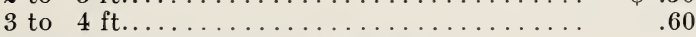

VARIEGATED-LEAVED WEIGELA

(Weigela nana variegata)

Very pretty, dense shrub; leaves variegated with white and yellow. Flowers clear rose in June.

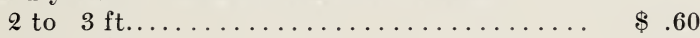

3 to $4 \mathrm{ft} \ldots \ldots \ldots \ldots \ldots \ldots \ldots \ldots \ldots \ldots \ldots \ldots \ldots \ldots \ldots \ldots . .75$

\section{BARBERRY}

JAPANESE BARBERRY (Berberis thunbergi)

Very popular low plant for ornamental hedges, edging shrubbery or massing, the fall and winter effect of its bright red berries and brilliant foliage being gorgeous; quick growing, dwarf shrub.
12 to 15 in
$\$ .25$
15 to 18 in
18 to 24 in.
.40

\section{NEW RED-LEAVED JAPANESE BARBERRY}

(Berberis thunbergi atropurpurea) A brilliant red-leaved Japanese barberry for mixing in the shrubbery border, as single specimens, or clumps on the lawn, foundation plantings and for hedges. The foliage is a rich, lustrous, bronzy red, similar to the richest red-leaved Japanese maples. To develop its brilliant coloring at all seasons it must be planted in full sunlight.

9 to 12 in...................... $\$ .50$

12 to 15 in....................... $\quad .60$

15 to 18 in.....................

18 to 24 in............... 1.00

\section{GLOBE SHAPED PRIVET}

\section{PRIVET}

This is California Privet carefully sheared in perfect balls. Specimen plants.

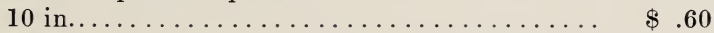

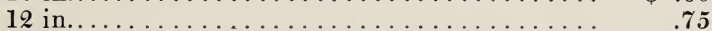

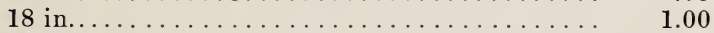

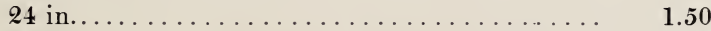

30 in............................ 2.00

STANDARD CALIFORNIA PRIVET

Tree form. Sheared round heads, straight stems.

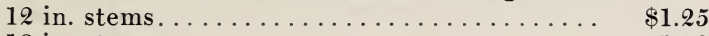

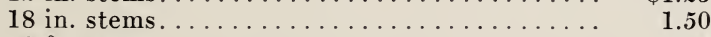

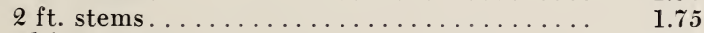

$21 / 2 \mathrm{ft}$. stems................... 


\section{GOLDEN VARIEGATED PRIVET}

Brilliant yellow foliage; dwarf, good in clumps among, or in front of, low evergreens or shrubs.

19 to 15 in....

15 to 18 in. $\ldots \cdots \cdots \cdots \cdots \cdots \cdots \cdots \cdots \cdots \cdots \cdots \cdots \cdots \cdots \cdots$

ALTHEA

(Hibiscus syriacus)

A large shrub, sometimes trimmed into tree form, that blooms freely in August or September, when almost every tree is out of bloom. Vigorous grower and succeeds everywhere. Also called Rose of Sharon. We can furnish double varieties in these colors: Purple, Red, Pink and White.

18 to 24 in...

$\$ .50$

2 to $3 \mathrm{ft}$.. .60

VARIEGATED-LEAVED ALTHEA

Leaves striped yellow; compact grower.

3 to $4 \mathrm{ft}$...

BUTTERFLY BUSH

$\$ .75$

So named because blooms attract large numbers of butterflies. This fact makes the plant very interesting, especially to children. Matures first year. Blooms profusely, lilac colored tapering panicles, 6 to 10 inches long. 18 to 24 in...................... $\$ .40$

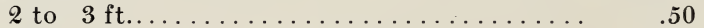

3 to $4 \mathrm{ft} . \ldots \ldots \ldots \ldots \ldots \ldots \ldots \ldots \ldots \ldots . .60 \ldots$

CHINESE BEAUTYBERRY (Callicarpa purpurea) Graceful branches, pink flowers in summer-violet red berries in fall.

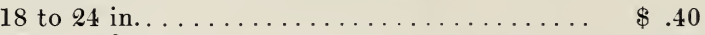

2 to $3 \mathrm{ft} . \ldots \ldots \ldots \ldots \ldots \ldots \ldots \ldots \ldots . \ldots . \ldots . .50$

FLOWERING QUINCE (Cydonia Japonica)

Large, scarlet flowers in masses in May, make this one of the most attractive of the spring-flowering shrubs. Foliage, dark glossy green.

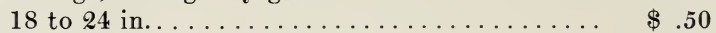

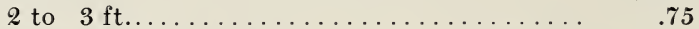

FLOWERING ALMOND (Amygdalus nana) Flowers double, May; very showy; there are Pink and White varieties.

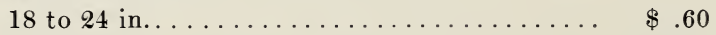

2 to $3 \mathrm{ft} \ldots \ldots \ldots \ldots \ldots \ldots \ldots \ldots \ldots \ldots \ldots . \ldots \ldots$

DOUBLE FLOWERING PLUM (Prunus triloba) Upright in growth; slender branches completely covered with double pink flowers before leaves appear. Foliage green.

18 to 24 in...................... $\$ .60$

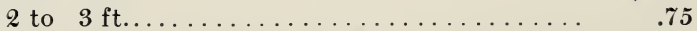

FORTUNE'S GOLDEN BELL (Forsythia fortunei) Spreading in growth; dark, shining foliage. Flowers in great profusion, very early.

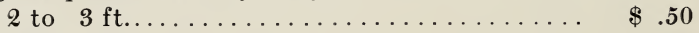

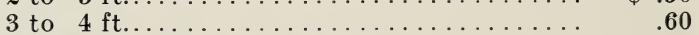

GOLDEN AMERICAN ELDER

(Sambucus canadensis a urea)

Has conspicuous yellow foliage.

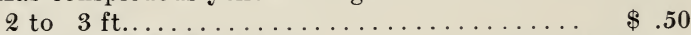

GOLDEN SHRUB ROSE (Rosa Hugonis)

A beautiful new yellow shrub rose from China.

12 to 18 in..

$\$ .75$

SWEETSHRUB

(Calycanthus floridus)

Much planted for its fragrant, strawberry-scented, chocolate-colored blossoms, spring and summer.

18 to 24 in. . . . . . . . . . . . . . . . . . . .

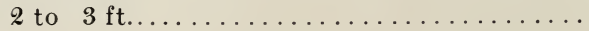

$\$ .60$ 


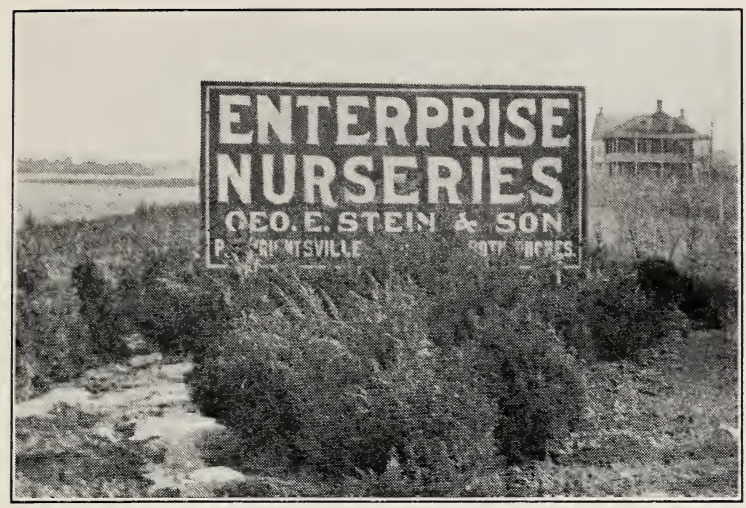

Our Sign and Some Evergreens at Our Branch Nursery at Yorkshire

\section{HEDGE PLANTS}

CALIFORNIA PRIVET. The most popular hedge plant on account of its beauty, adaptability, and low cost. Did you ever realize what an admirable and luxuriant privet hedge you could secure at a very small cost, and how much it would add to the value of your property? To find the exact number wanted, measure the space where it is to be planted and multiply the number of feet by two.

They should be planted 3 inches deeper than they stood in the nursery row. Set the plants 6 inches apart in the row. Dip the roots in water before planting. After plants are set, cut them down to 4 inches from the surface of the ground. This will cause a thick new growth to start and is very essential for a beautiful hedge.

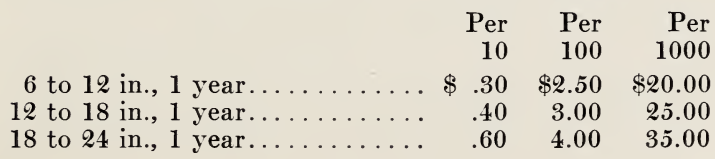

Two-year cut back last spring, this has made a bushy, well branched plant, the one to use for immediate effect.

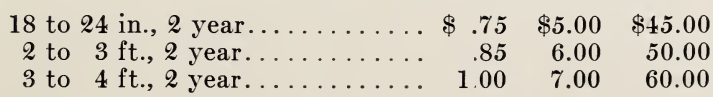

JAPANESE BARBERRY

(Berberis thunbergi)

The best low, dense, hedge plant grown. Leaves very green and attractive during summer months, turning a rich crimson in autumn, branches drooping with loads of bright red berries which hang on until late winter.

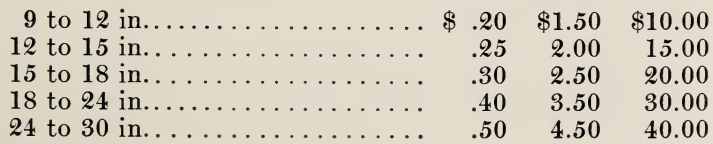

Many of our Ornamental Shrubs and Evergreens make splendid Hedges, Screens and Windbreaks. 


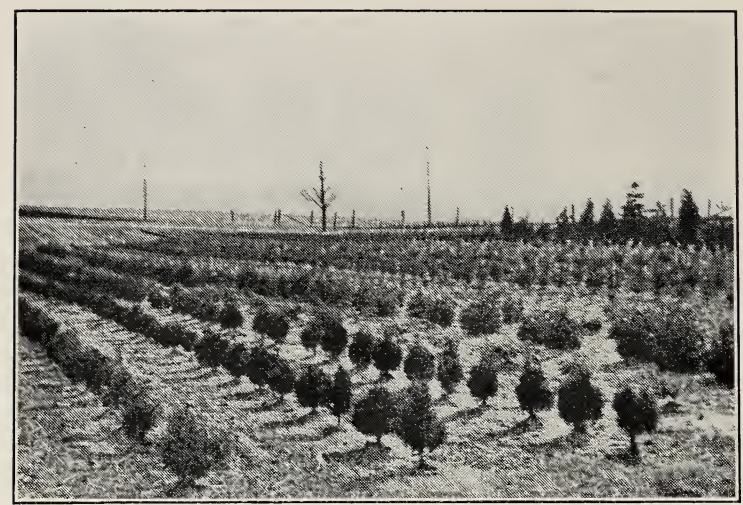

A Block of Splendid Young Evergreens

\section{EVERGREENS}

Our Evergreens are compact, nicely shaped specimen plants. They will be balled and burlapped, that is, carefully dug with the proper amount of soil about the roots and wrapped in burlap. These prices include this service.

\section{ARBORVITAES}

AMERICAN ARBORVITAE (Thuja occidentalis) Slender pyramid with broad base. Bronzy winter coloring. Good accent plant or for a hedge.

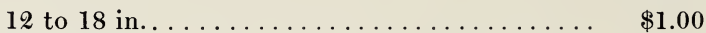

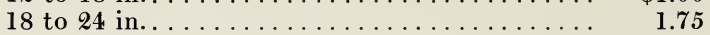

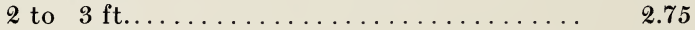

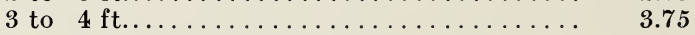

\section{COMPAC'T PARSONS' ARBORVITAE}

(Thuja occidentalis compacta) Almost globe-shaped. Bright green. Useful in formal or foundation planting.

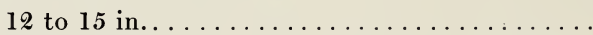

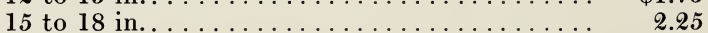

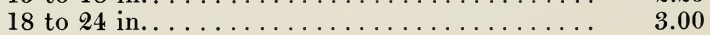

\section{GOLDEN-TIPPED ARBORVITAE}

(Thuja occidentalis elegantissima) Rich, lustrous green foliage; branches tipped with yellow.

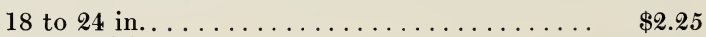

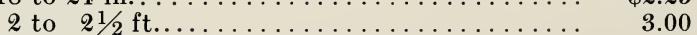

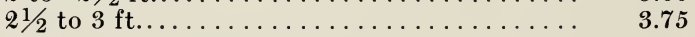

GLOBE ARBORVITAE (Thuja occidentalis globosa) Useful in formal work. Naturally globe-shaped.

10 to 12 in. . . . . . . . . . . . . . . . . . $\$ 1.50$

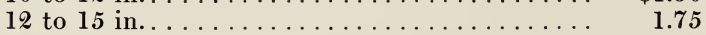

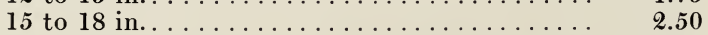

HOVEY ARBORVITAE (Thuja occidentalis hoveyi) Oval in shape, nearly as broad as high. Bright green foliage.

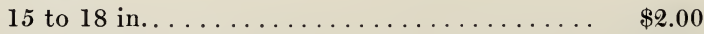

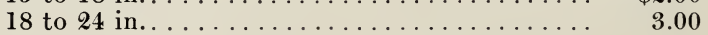




\section{GEORGE PEABODY ARBORVITAE}

(Thuja occidentalis lutea)

Conspicuous golden yellow form. Columnar outline.

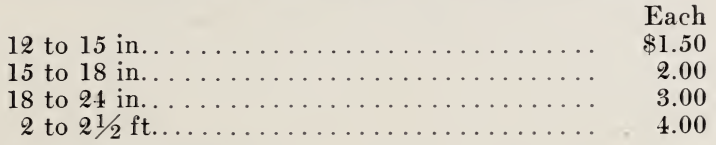

MOSS ARBORVITAE (Thuja occidentalis plicata) Rich, deep blue-green foliage. Short, stiff branchlets give pleasing effect in light and shade. Formal pyramid.

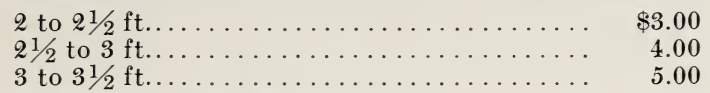

\section{PYRAMIDAL ARBORVITAE}

(Thuja occidentalis pyramidalis) Retains bright green coloring throughout winter. Narrow columnar shape; splendid for accents or formal planting.

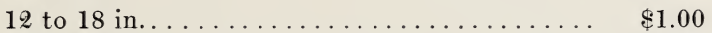

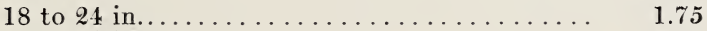

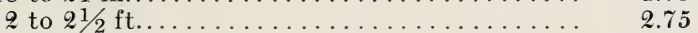

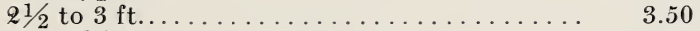

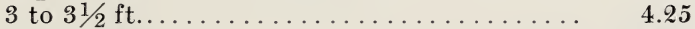

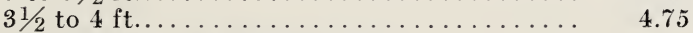

\section{ROSENTHAL'S ARBORVITAE}

(Thuja occidentalis rosenthali)

Dense, rugged, columnar form. Slow grower.

15 to 18 in. . . . . . . . . . . . . . . . \$2.00

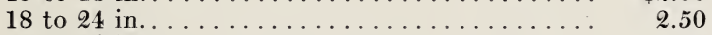

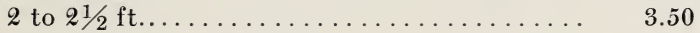

\section{SIBERIAN ARBORVITAE}

(Thuja occidentalis sibirica)

Light green, fleshy foliage. Broadly pyramidal, rugged in appearance.

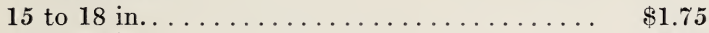

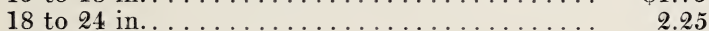

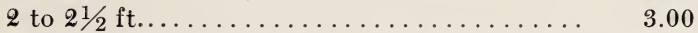

\section{CHINESE ARBORVITAE (Biota orientalis)}

Evergreen. Rather stiff, columnar habit; bright green foliage, bronze in winter; a good accent plant.

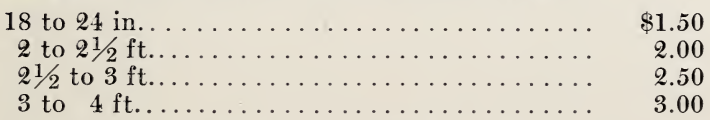

\section{BERKMAN'S GOLDEN ARBORVITAE}

(Biota aurea nana) A gem for dwarf planting; compact, roundish shape; warm golden yellow foliage. Especially good for formal work and edging.

6 to 8 in

$\$ 1.25$

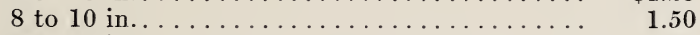

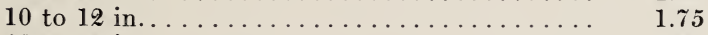

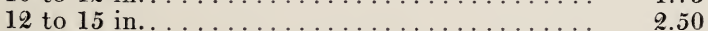

\section{YELLOW COLUMN ARBORVITAE}

Assumes a rich, deep golden bronze color in winter. Compact, columnar.

18 to 24 in. . . . . . . . . . . . . . $\$ 2.50$

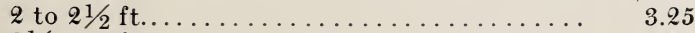

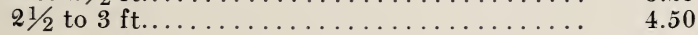




\section{GEDARS}

RED GEDAR

(Juniperus virginiana) Forms a dense column, deep green foliage, purplish in winter. Useful in formal work, or mixed plantings.

18 to 24 in $\ldots \ldots \ldots \ldots \ldots \ldots \ldots \ldots \ldots \ldots, \quad \$ 1.50$

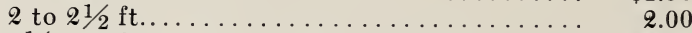

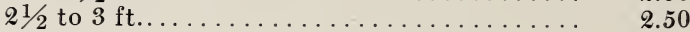

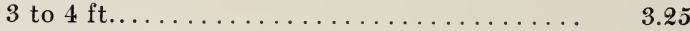

VIRGINIA BLUE GEDAR (Juniperus virginiana glauca) Broadly conical form and beautiful glaucous blue foliage makes it one of the choicest Junipers.

18 to 24 in. . . . . . . . . . . . . . . . $\$ 2.50$

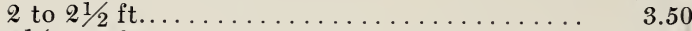

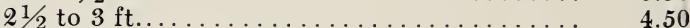

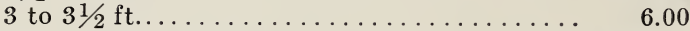

SCHOTT RED CEDAR (Juniperus virginiana schotti) Has fresh green foliage. Compact formal columnar habit. Good winter color, quite hardy. Quite amenable to trimming.

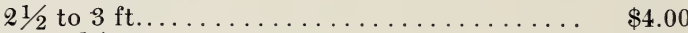

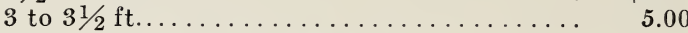

\section{FIRS}

WHITE FIR

(Abies concolor)

Grows quickly and forms symmetrical, beautiful specimen. Large, gray-green needles.

15 to 18 in. . . . . . . . . . . . . . . $\$ 3.00$

18 to 24 in........................ 4.00

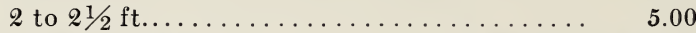

DOUGLAS FIR

(Abies douglassi)

Very hardy; dark bluish-green coloring. Prefers welldrained situation.

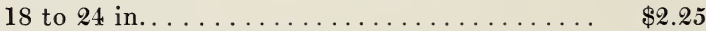

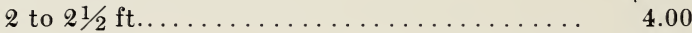

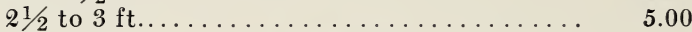

\section{HEMLOCK}

GANADIAN HEMLOCK

(Tsuga canadensis)

An elegant pyramidal tree with drooping branches and delicate dark green foliage. Excellent for lawn purposes, also suited for hedges. Does well in shady or sunny locations.

18 to 24 in. . . . . . . . . . . . . . . . . \$2.25

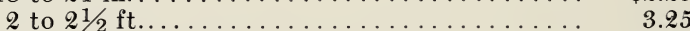

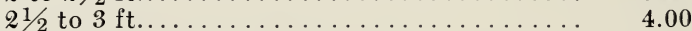

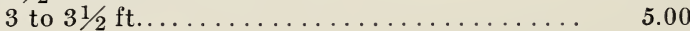

\section{JUNIPERS}

PFITZER'S JUNIPER (Juniperus chinensis pfitzeriana) Broad, bushy habit. Gray-green foliage, giving feathery appearance. A most adaptable hardy evergreen; highly recommended.

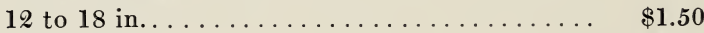

18 to 24 in...................... 2.50

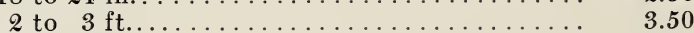

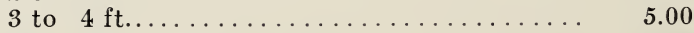

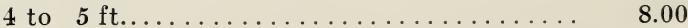

GOLDEN JUNIPER (Juniperus communis aurea) Low spreading habit. Golden foliage, particularly bright in spring.

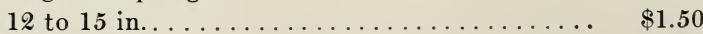

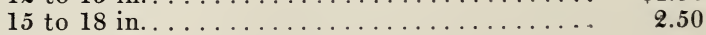




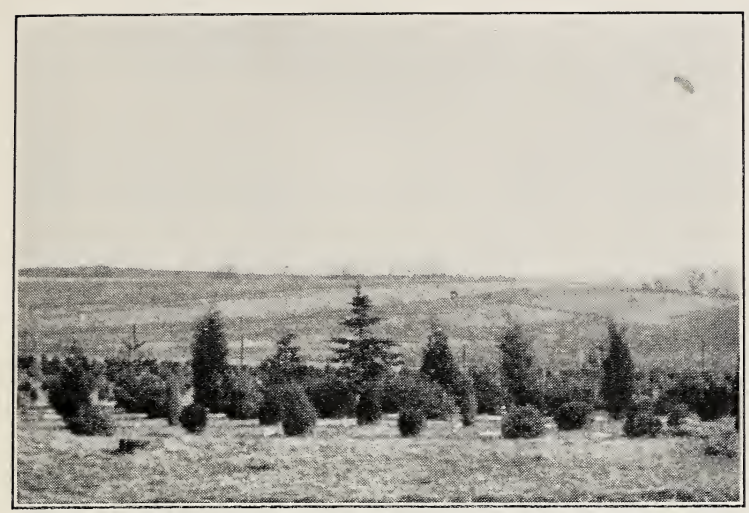

Group Planting of Specimen Evergreens at the Nursery

IRISH JUNIPER (Juniperus communis hibernica) Slender, columnar form, compact bluish-green foliage. Formal type.

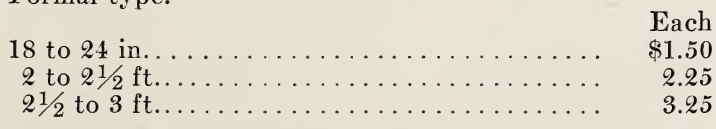

SPINY GREEK JUNIPER (Juniperus excelsa stricta) Compact, well-shaped pyramid. Foliage gray-green. Most useful for formal effects.

10 to 12 in...................... $\$ 1.50$

12 to 15 in................ $\quad 2.00$

15 to 18 in..................... 3.00

18 to 24 in.................... 4.00

\section{WAUKEGAN JUNIPER}

(Juniperus horizontalis douglasi) Long branches trailing along ground. Steely-blue foliage. A splendid ground cover; also effective among rock. Distinct purple hue in winter.

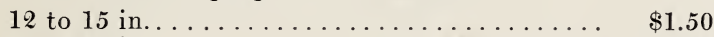

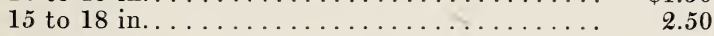

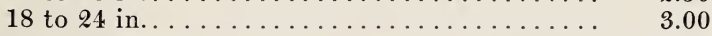

SAVIN JUNIPER (Juniperus sabina) Dense, dark green foliage. Spreading branches, forming irregular vase-shaped bush.

12 to 15 in. . . . . . . . . . $\ldots \ldots \ldots \ldots$

15 to 18 in........................ 2.00

18 to 24 in....................... 3.00

\section{PINES}

MUGHO DWARF PINE (Pinus montana mughus) Forms a round-topped clump. Useful for rock planting and foundation work.

10 to 12 in................. $\$ 1.50$

12 to 15 in.............. $\quad 2.25$

15 to 18 in............... 3.25

AUSTRIAN PINE (Pinus nigra)

Rich, dark green. Vigorous, dense grower. Grood for background.

18 to 24 in . . . . . . . . . . . . . . . . . . \$ $\$ 2.00$

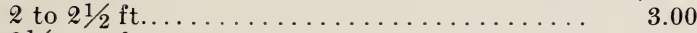

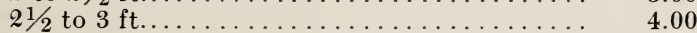

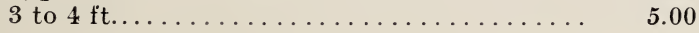


WHITE PINE

(Pinus Strobus)

Probably our most adaptable and useful pine. Very picturesque when old.

18 to $24 \mathrm{in}$.

Each

$\$ 2.00$

SCOTCH PINE

(Pinus sylvestris)

A rapid-growing, handsome tree, especially when young. Good for windbreaks.

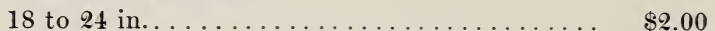

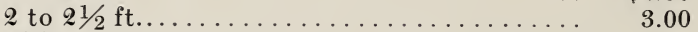

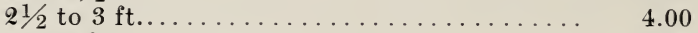

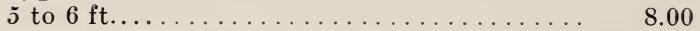

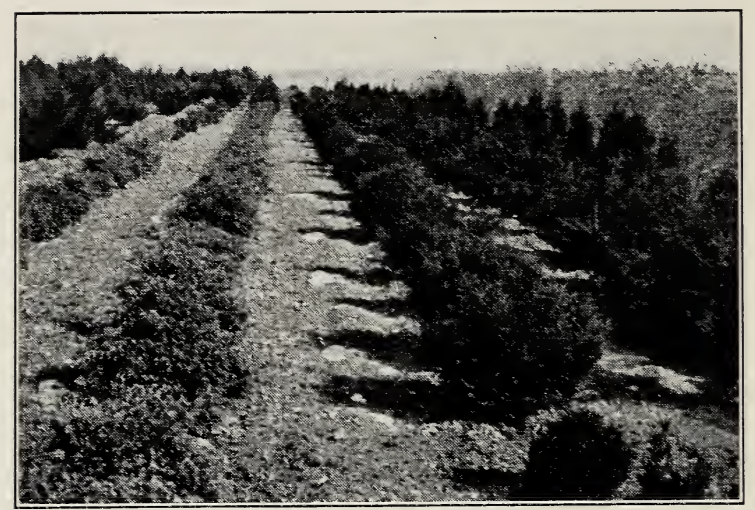

Here are Some Nice Evergreens to Beautify Your Home

\section{RETINOSPORAS}

\section{GOLDEN SAWARA RETINOSPORA}

(Retinospora pisifera aurea)

Bright golden form, holding its color.

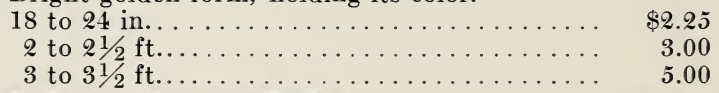

THREAD RETINOSPORA (Retinospora filifera)

Has long, stringy, drooping branches and bright green foliage. Graceful and decorative.

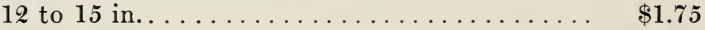

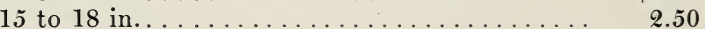

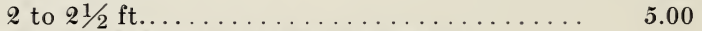

\section{GOLDEN THREAD RETINOSPORA}

(Retinospora filifera aurea) Very bright, conspicuous, golden yellow. Grows more slowly than preceding.

10 to 12 in.................... \$2.00

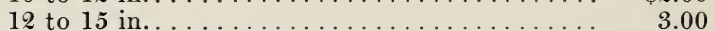

PLUME RETINOSPORA (Retinospora plumosa)

Forms a dense cone of fine texture. Useful for shearing into formal shapes.

15 to 18 in..................... $\$ 1.50$

18 to 24 in. . . . . . . . . . . . . .

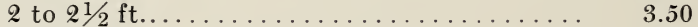

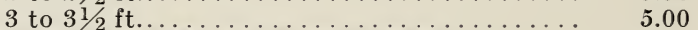

GOLDEN PLUME RETINOSPORA

(Retinospora plumosa aurea)

Golden form of preceding, and grows more slowly.

12 to 15 in. . . . . . . . . . . . . . . . $\$ 1.50$

15 to 18 in. . . . . . . . .

18 to 24 in.......................... 3.00

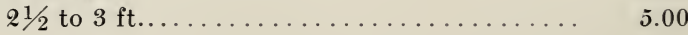




\section{VEITCH'S RETINOSPORA}

(Retinospora squarrosa veitchi) Foliage blue-gray, feathery and dense, giving soft woolly appearance. Broad pyramidal outline when young.

15 to 18 in. .................... \$2.00

18 to 24 in. . . . . . . . . . . . . . . . $\quad 3.00$

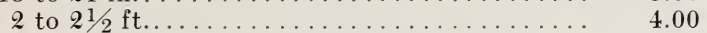

\section{SULPHUR-TIPPED RETINOSPORA}

(Retinospora squarrosa sulphurea) Round, dense grower, with soft yellowish green foliage. 12 to 15 in.................... \$2.00

15 to 18 in........................ 2.50

18 to 24 in....................... 3.50

HEATH RETINOSPORA (Retinospora ericoides) Has heather-like leaves, giving woolly effect. Forms a round, broad bush.

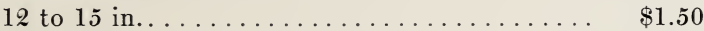

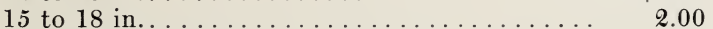

18 to 24 in..................... 2.50

\section{SPRUCES}

NORWAY SPRUCE

(Picea excelsa) Has dark green foliage and grows rapidly. Makes a good windbreak, and also lends itself well to trimmed hedges.

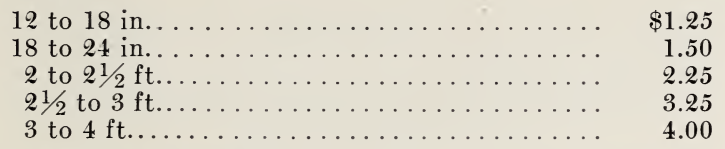

\section{COLORADO SPRUCE}

(Picea pungens)

Has abundance of heavy foliage of a light green color; pyramidal and regular in shape.

12 to 18 in. . . . . . . . . . . . . . . . . $\$ 1.50$

18 to 24 in....................... 2.50

BLUE COLORADO SPRUCE (Picea pungens glauca) Branches in distinct whorls, forming handsome lawn specimen.

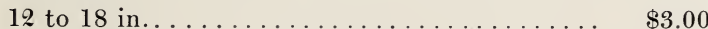

18 to 24 in..................... 5.00

\section{YEWS}

\section{SPREADING ENGLISH YEW}

(Taxus baccata repandens) Spreading, horizontal branches, dark blue-green leaves. Valuable for low planting.

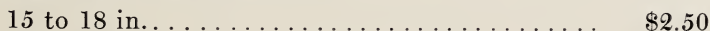

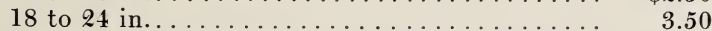

JAPANESE SPREADING YEW (Taxus cuspidata) Rich, deep green leaves. Spreading, bushy habit. Valuable in foundation plantings. Exceptionally hardy.

18 to 24 in. . . . . . . . . . . . . . . . . . \$ $\$ 4.50$

\section{DWARF JAPANESE YEW}

(Taxus brevifolia)

Broad, thick leaves, blackish green. Slow growing and irregular, spreading habit. Exceptionally hardy.

12 to 15 in. . . . . . . . . . . . . . . . . . . . \$ \$3.00 


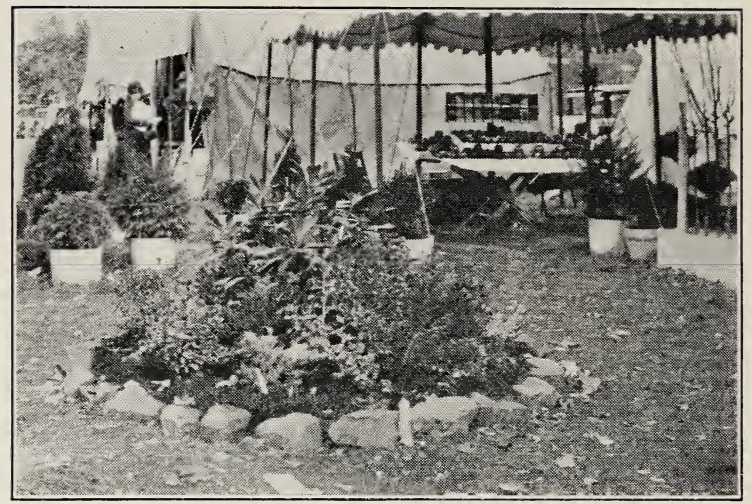

Part of Our Exhibit at York Fair-Showing a Rock Planting

\section{BROAD-LEAVED EVERGREENS}

Because they hold their rich green foliage all the year round and in many varieties make a magnificent showing of bloom, the Broad-Leaved Evergreens will always be popular. Some of the most gorgeous flowering plants are to be found in this class. Shaded situations are preferred by most of the varieties.

\section{AZALEAS}

AZALEA AMOENA

Conspicuous purple-red flowers, April-May. Leaves turn a rich, bronze-green in winter.

8 to 10 in.

Each

$\$ 2.00$

10 to 12 in..................... 2.50

\section{AZALEA HINODEGIRI}

Larger leaves and looser growth than above; flowers very bright carmine-pink; effective in masses or with Rhododendron.

8 to 10 in. . . . . . . . . . . . . . . . . $\$ 2.00$

10 to 12 in. . . . . . . . . . . 2.50

\section{BOXWOODS}

BOXWOOD (Buxus sempervirens) Useful for formal hedges. Specially desired for planting as individual specimens on lawns or in tubs.

10 to 12 in.................... $\$ 1.50$

12 to 15 in...................... 1.75

15 to 18 in......................... 2.00

18 to 24 in..................... 3.00

DWARF ENGLISH BOXWOOD (Buxus suffruticosa) A very low growing variety, used for window boxes and edgings around beds of shrubbery or along walks, etc.

4 to 6 in................. $\$ .20 \quad \$ 1.75$

6 to 8 in. $\ldots \ldots \ldots \ldots \ldots \ldots \ldots \ldots \ldots$

8 to 10 in.................. $1.00 \quad 7.50$

\section{EUONYMUS}

EVERGREEN BURNING BUSH (Euonymus japonicus) Lustrous, deep green leaves; upright bushy habit. 
12 to 15 in.................... $\$ 1.00$

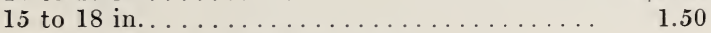

SILVERSPOT BURNING BUSH

Dwarf, type silver variegated leaves.

8 to $10 \mathrm{in.}$

GOLDSPOT BURNING BUSH

Variegated golden color.

8 to 10 in.

$\$ 1.00$

\section{HOLLY}

AMERICAN HOLLY

(Ilex opaca)

This is our native holly, which is so popular over the Christmas season.

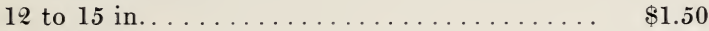

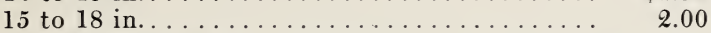

JAPANESE HOLLY

(Ilex crenata)

Shrub with glossy, dark green leaves and black berries.

12 to 15 in. . . . . . . . . . . . . . . \$2.00

\section{RHODODENDRON}

\section{RHODODENDRON MAXIMUM}

Beautiful light pink flowers freely produced in MayJune. Large handsome foliage, most effective in masses. 12 to 15 in . . . . . . . . . . . . . . . . . . $\$ 1.00$

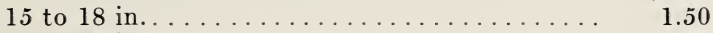

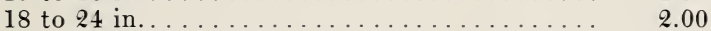

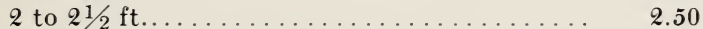

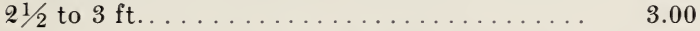

\section{HYBRID RHODODENDRONS}

Hardy named varieties, Pink, Red, White and Purple.

15 to 18 in..................... $\$ 5.00$

18 to 24 in................... 6.00

\section{OTHER LEADING VARIETIES OF BROAD-LEAVED EVERGREENS}

BUSH ARBUTUS

(Abelia grandiflora) Choice small shrub, with white tinted lilac flowers, produced throughout the entire summer months.

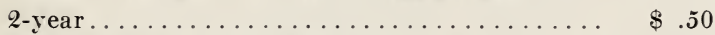

LEUCOTHOE CATESBAEI (Drooping Leucothoe) Attractive white flowers, May. Handsome lustrous leaves, rich autumn coloring. Splendid for under planting in shade.

12 to 15 in. . . . . . . . . . . . . . $\$ 2.00$

MAHONIA AQUIFOLIUM (Oregon Holly Grape)

Shining green leaves, turn rich scarlet in Autumn; striking in May when yellow flowers appear; blue-black fruits. Best in half shade.

12 to 15 in. . . . . . . . . . . . . . . . $\$ 1.50$

15 to 18 in...................... 2.00

\section{ORNAMENTAL CLIMBING VINES}




\section{CLEMATIS PANICULATA}

The flowers are of medium size, fragrant, pure white, borne in immense sheets in September.

2-year, first-class................. $\$ .50$

\section{EUONYMUS VARIEGATUS}

(Variegated Leaf Wintercreeper) Leaves veined and marked yellowish white and pink. Clinging vine.

2-year .

\section{WISTERIA SINENSIS}

(Chinese Wisteria) Good for pergolas, porches and trellises; dense drooping clusters of pea-shaped purple-blue flowers.

2 to $3 \mathrm{ft} . \ldots \ldots \ldots \ldots \ldots \ldots \ldots \ldots \ldots$

\section{HARDY PERENNIAL PLANTS}

\section{ASTILBE JAPONICA HYBRIDS (Spirea)}

AMERICA. Deep pink; excellent forcing variety.

BRUNHILDE. Creamy white, shaded lilac.

PHILADELPHIA. Flowers are bright pink.

PEACHBLOSSOM. A beautiful peachblossom pink.

GLADSTONE. Best white variety.

We offer 3-year-old, large, field-grown clumps for immediate effect.

Each

$\$ .75$

\section{HARDY PHLOX}

Perennial Phloxes succeed in almost any soil enriched with manure in Spring, and in hot weather an occasional soaking of water. If the first spikes of bloom are removed as soon as over, they will produce a second supply of flowers, continuing the display until late in autumn.

CHAMPS ELYSEE. Rosy purple: very effective.

RIJNSTROOM. Beautiful rose pink.

THOR. Salmon-rose, with scarlet glow.

W. C. EGAN. Lilac, with bright solferino eye.

RIVERTON'S JEWEL. Mauve-rose.

R. P. STRUTHERS. Cherry-red, suffused salmon.

RHEINLANDER. Salmon-pink.

MRS. JENKINS. Flowers large, pure white. Early. Free bloomer.

MISS LINGARD. Earliest white; pale pink eye. Long, graceful panicles.

Strong, 2-year field-grown............. \$.25

\section{ROSES}

The list we offer is not a large one but contains the "cream" of the ones which thrive best here. Our roses are two-year field-grown, were dug in the Fall and are planted in six-inch pots. In this way they will be sure to grow, and bloom in a very short time.

\section{HYBRID TEAS OR EVERBLOOMING ROSES}

$\$ 1.00$ Each, $\$ 8.50$ Per 10

JONKHEER J. L. MOCK. A new pink rose from Holland; vigorous in growth and hardy.

RADIANCE. Carmine-pink, yellow at base of petals. 
RED RADIANCE. Dazzling crimson-scarlet.

LOS ANGELES. Luminous flame-pink, toned coral, shaded translucent gold at base of petals.

GRUSS AN TEPLITZ. Scarlet; constantly in bloom.

SOUVENIR DE CLAUDIUS PERNET. Sunfloweryellow.

ETOILE DE FRANCE. Vivid crimson, with darker shadings.

FRAU KARL DRUSCHKI. White; constant bloomer. Best white rose.

SUNBURST. Rich yellow, shaded coppery orange.

DOUBLE WHITE KILLARNEY. Waxy white.

COLUMBIA. Glowing pink.

MME. BUTTERFLY. Bright pink, apricot and gold.

MRS. AARON WARD. Dark yellow; almost orange.

\section{CLIMBERS AND RAMBLERS}

CLIMBING AMERICAN BEAUTY. Plant a vigorous grower. Color red, same as the famous old American Beauty. Wonderfully free bloomer.

WHITE DOROTHY PERKINS. Rambler. In June and July this one produces immense trusses of delightful white flowers. Hardiest of all roses.

\section{SUCGESSFUL PLANTING, PRUNING AND GARE}

\section{CARE OF STOCK}

The bundles should be opened immediately, the roots dipped in water, then heeled in moist ground so that the mellow earth will come in contact with the roots and thoroughly protect them from the air, having the earth tramped solid about them.

When ready to plant, take up only a few at a time, puddle the roots and do not allow them to lie exposed to the sun or air.

The ground should be carefully prepared by deep plowing and firming down with a disc and harrow.

\section{PLANTING}

The holes for planting must be large enough to receive the roots freely, without cramping or bending them from their natural position. All broken or mutilated portions of the roots must be cut off so as to leave the ends smooth and sound. All trees should be planted two or three inches deeper than they stood in the nursery row; pack the soil very firmly about the roots by tamping with the feet or post tamper, being careful not to bark or break the roots. Leave three inches of the surface soil loose to serve as a mulch. If the ground is very dry apply one to two pails of water before this soil mulch is in place, and after the water has soaked away it can then be placed over the moist soil.

\section{PRUNING}

Many failures of newly transplanted stock are due to the lack of proper pruning. When the trees are dug in the nursery, some of the feeding roots are left in the ground, therefore, when transplanting it is necessary to restore the balance between the roots and the top by removing part of the tops. 
In pruning, make a clean, sharp cut. Do not leave stub ends in removing branches. Pruning shears, knives and hand saws are the best tools to use. All tools should be sharp.

FRUIT TREES. One of the most important items in the care of fruit trees is to see that they are trained right from the start. Our two-year-old and larger sizes have the heads already formed, with three to five scaffold limbs well arranged along the trunk to support the head. These trees should be cut back, leaving just the scaffold limbs shortened to the point where it is desired to have the head of the tree.

One-year trees, or whips, should be trimmed to smooth, straight stems, cutting them squarely off at the distance from the ground at which it is desired to have them branch. Usually, apples, plums, pears, and cherries are headed a little higher than peaches, which ought to be encouraged to branch as low as possible.

SHADE TREES. With shade trees having a heavy top, at least one-third of the top should be removed. Prune to avoid crowding branches. Cut out some of the small branches, shorten back the side branches, but do not cut off the leader or main stem. Try to get well developed head, strong leader and branches at wide, not close, angles. Cut off all broken roots.

SHRUBS. It is easiest to prune shrubs before they are planted. This is likewise the only time the roots can be pruned. Cut off damaged or frayed roots just above the point affected. Thin out tops of many branched shrubs, removing the old wood. Cut tops back from one-third to one-half.

EVERGREENS. At planting time evergreens seldom need pruning. If well grown like ours they are shapely and when handled with balls of soil they should grow off without trouble. However in a year or so more varieties are inclined to grow "open." Then shearing may be done with hedge tools, clipping the young growth, preferably not further than that made the previous season. This causes the inner branches to advance making a very close and compact plant, thus hiding the unsightly interior of open trees. Topping, too, may be done but please try and cut to a small branch that will again develop into a leader. Chopping the tops off flat often makes good trees resemble a sawed-off board or log. Important-Prune evergreens when they are growing-better just as the spring growth comes on and at least before it becomes hard in July.

WINTER PROTECTION FOR EVERGREENS. Evergreens during the first Winter after planting should have some form of protection. Wind and sun may cause damage on account of excessive evaporation of moisture from the foliage at a time when no moisture is being taken in through the roots. When subject to alternate freezing and thawing protect also against heaving of the soil.

Moisture evaporation may be prevented by the erection of a burlap shield as a windbreak to ward off strong, drying winds. Avoid wrapping too tightly or injury to the plant will result from heating of foliage.

To prevent heaving of the soil provide a ground mulch of strawy manure, cut tobacco stems or any material (other than fresh manure) which will form a light, loose covering.

Be sure, too, that the ground is thoroughly saturated with moisture before it finally freezes up, and leave no holes near the plants for the water to collect and freeze. 
MEMORANDA 
MEMORANDA 


\section{SUITABLE DISTANGE FOR PLANTING}

Apples-30 to 40 feet apart each way.

Standard Pears and Cherries-20 feet apart each way.

Plums, Peaches and Apricots-16 to 18 feet apart each way. Dwarf Pears and Quinces-10 to 12 feet apart each way.

Grapes-rows of 10 to 16 feet apart; 7 to 10 feet in rows.

Currants and Gooseberries-4 feet apart.

Raspberries and Blackberries-3 to 4 by 5 to 7 feet.

Strawberries, for field culture -1 by 3 to $31 / 2$ feet.

Strawberries, for garden culture- 1 to 2 feet apart.

Asparagus, for field culture-18 to 24 inches by $31 / 2$ to 4 feet.

Asparagus, for garden culture-18 to 24 inches apart each way.

NUMBER OF TREES OR PLANTS TO THE ACRE

40 feet apart each way............... 28

30 feet apart each way................ 48

20 feet apart each way................ 110

18 feet apart each way................. 135

15 feet apart each way................. 205

12 feet apart each way................. 300

10 feet apart each way................ 435

8 feet apart each way............... 680

6 feet apart each way................. 1,210

5 feet apart each way. . . . . . . .

4 feet apart each way. . . . . . . . . .

3 feet apart each way. . . . . . . . . . . 4,840

Rule-Multiply the distance in feet between the rows by the distance the plants are apart in the rows, and the product will be the number of square feet for each plant, which, divided into the number of square feet in an acre $(43,560)$, will give the number of plants or trees to the acre. 


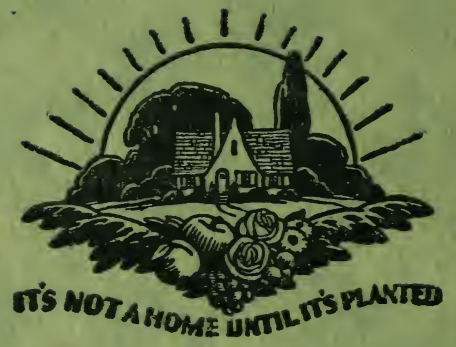

